IZA DP No. 8261

The Power of the Little Blue Pill:

Innovations and Implications of Life Style Drugs in an Aging Population

Jacob LaRiviere

Hendrik Wolff

June 2014 


\title{
The Power of the Little Blue Pill: Innovations and Implications of Life Style Drugs in an Aging Population
}

\author{
Jacob LaRiviere \\ University of Tennessee \\ Hendrik Wolff \\ University of Washington \\ and IZA
}

\section{Discussion Paper No. 8261 \\ June 2014}

IZA
P.O. Box 7240
53072 Bonn
Germany

\author{
Phone: +49-228-3894-0 \\ Fax: +49-228-3894-180 \\ E-mail: iza@iza.org
}

\begin{abstract}
Any opinions expressed here are those of the author(s) and not those of IZA. Research published in this series may include views on policy, but the institute itself takes no institutional policy positions. The IZA research network is committed to the IZA Guiding Principles of Research Integrity.

The Institute for the Study of Labor (IZA) in Bonn is a local and virtual international research center and a place of communication between science, politics and business. IZA is an independent nonprofit organization supported by Deutsche Post Foundation. The center is associated with the University of Bonn and offers a stimulating research environment through its international network, workshops and conferences, data service, project support, research visits and doctoral program. IZA engages in (i) original and internationally competitive research in all fields of labor economics, (ii) development of policy concepts, and (iii) dissemination of research results and concepts to the interested public.
\end{abstract}

IZA Discussion Papers often represent preliminary work and are circulated to encourage discussion. Citation of such a paper should account for its provisional character. A revised version may be available directly from the author. 


\section{ABSTRACT \\ The Power of the Little Blue Pill: Innovations and Implications of Life Style Drugs in an Aging Population ${ }^{1}$}

The launch of Viagra in April 1998 led to a historically unprecedented high usage of erectile dysfunction (ED) drugs. We test whether Viagra's introduction significantly influenced outcomes for its target population such as STD rates of older men, as well as its non-target populations, such as divorces, natality, the distribution of the age spread within couples, female STDs and sexual assault rates. We find causal evidence that Viagra's introduction increased Gonorrhea rates in older men by $15-28 \%$. We find no significant evidence of any effects on other variables. We take this as evidence that this lifestyle drug causes significant changes in choices only which affect short term outcomes, while long term planned decisions are unaffected. Overall, we find that the welfare impacts of Viagra with respect to our outcomes of interest are positive and large.

JEL Classification: I1, J1, O33, J31

Keywords: $\quad$ prescription drugs, STD, aging population, Viagra, differences-in-differences

Corresponding author:

Hendrik Wolff

University of Washington

349 Savery Hall

Box 353330

Seattle, WA 98195-3330

USA

E-mail: hgwolff@uw.edu

\footnotetext{
${ }^{1}$ This paper is forthcoming in Economic Inquiry. When citing the paper, please refer to the journal version.

We are indebted to Max Auffhammer, Ron Lee and David Zilberman for valuable discussions and suggestions. We are also grateful for helpful student research assistance by Reid Johnsen, Mingyuan Hua, Ling Ma, Jennifer Meredith, Dorian Sidhu and Stephanie Thomas. Any mistakes are the authors'.
} 


\section{Introduction}

How do innovations in medical technology targeted to the elderly affect the decision making of an aging population? This is an increasingly important question as more resources and R\&D are dedicated to the health care of a growing elderly age cohort in the U.S. While the direct health benefits of medical innovations are well studied, the effects of a new class of drug on behavioral decisions of the elderly remains largely unexplored in the literature (Cutler and McClellan 2001 and Cutler 2007). ${ }^{2}$

The 1998 approval of Viagra, informally known as the "little blue pill”, offers an ideal natural experiment to identify how one particular medical innovation targeted at the elderly affects their behavior. Before 1998, men suffering from erectile dysfunction (ED) had very limited treatment possibilities. Upon FDA approval in April of 1998 Viagra was rapidly adopted. Sales soared and made the drug a tremendous commercial success for its producer-Pfizer. Since Viagra is targeted to older men, its introduction enables an increased supply of sexually active older men. As a result, the equilibrium decision making of the older population may have been affected leading to several changes in a large set of behavioral outcomes.

We examine Viagra's effect on five different dimensions: adoption of the new class of oral ED drugs and collapse of the traditional ED market, fatherhood decisions by age, the age composition of the marriage/divorce market, sexually transmitted diseases (STDs) and sexual assault and rape rates. Each variable of interest is chosen to highlight different channels through which this lifestyle drug could affect the target population, as well as produce spillover effects on non-target populations. First, we test for Viagra's impact on the number of children fathered by older men. This is a variable of interest because it highlights the drug's capacity to correct a physical disorder and the resulting immediate impact on child

\footnotetext{
2 There are at least two channels through which medical innovations could affect decision making of the elderly. First, medical innovations can enable specific behavior that was previously made impossible due to age or disease For example, a hip replacement or medication can enable exercise. Second, if medical innovations extend the expected lifespan of a population, it can indirectly affect decisions related to financial planning and years worked. We are concerned with the first channel in this paper.
} 
bearing decisions. ${ }^{3}$ Second, we test for Viagra's effect on sorting in the marriage market by analyzing changes to the distribution in the age spread among couples as well as divorce rates across age cohorts. These outcomes highlight the importance of the drug on the household production function. Third, we test for Viagra' effect on one particular STD, gonorrhea. STDs are of interest because it studies the drug's capacity to impact risky behavior associated with instant gratification. Lastly, we test for Viagra’s impact on rape committed by the target population (e.g., older men). This is an important variable due to the magnitude of consequences for victims. It also highlights the drugs capacity to impact unlawful behavior in individuals that previously were not physically able to commit such behavior. In sum, then, we test whether this particular lifestyle drug has an observable effect on four different behavioral channels: newly enabled family planning decisions, equilibrium in the marriage market, newly enabled risky behavior associated with instant gratification, and newly enabled criminal behavior.

The USA has the highest Viagra usage per capita of any country in the world. We therefore collected a rich set of both U.S. state and county level data for our outcome variables of interest. For each variable we use a difference-in-difference estimator to test how Viagra differentially affects outcomes in our treatment and control groups. Upon Viagra' approval in the US in April 1998, nearly 90\% of Viagra users were over 45 years of age. Therefore, our treatment group is individuals age 45 and above and our control group is individuals age 25-40. ${ }^{4}$ We show convincing evidence that short run fluctuations like macroeconomic conditions affect both the treatment and control groups in similar ways. To handle variables with a small number of observations, we employ both a trimming rule that drops certain counties in addition to a Poisson estimator which can more readily handle data with a low number of observations in the data.

\footnotetext{
${ }^{3}$ We want to highlight here we mean immediate impacts. In the longer run there could be additional family planning effects as younger men choose to delay having children longer due to the existence of ED drugs. Further, fatherhood can clearly be unplanned as well for both older and younger men. As a result, we are testing for an effect of Viagra's introduction generally on all births, both planned and unplanned, fathered by the older age cohort.

${ }^{4}$ We show that the age composition of Viagra users stays roughly constant from the first years of its introduction in 1998 through 2007.
} 
In order to interpret our estimates as causal, we have to show the following chain of events: first, the FDA approval leads to the adoption of the drug in the target population (both married and unmarried older men). We show convincing evidence that this occurs. Secondly, the target population changes their sexual behavior upon adoption of the drug. Unfortunately, there is no nationally representative dataset which documents the sexual behavior of the elderly which we could examine around the introduction of Viagra in April 1998. In lieu of direct data on sexual behavior, we directly collected state and county level data on outcome variables of interest. Given that we collect data on outcome variables as opposed to sexual behavior directly, there must be no other simultaneous changes which affect Viagra's target population around the date of Viagra's introduction. This motivates our differences-in-differences identification strategy in which the control group (individuals age 25-40) control for changes in sexual activity in the nation as a whole. Third, the observed change in behavior by the target population must lead to measurable changes in our outcomes of interest in the target and non-target population (e.g., older women).

We find that Viagra had a positive and significant effect on gonorrhea rates among men in the older population: rates increased by $15-28 \%$ in this group relative to the control. This result is robust across a variety of specifications and robustness checks. We find weak evidence that there was a smaller increase in women, but those estimates are less consistent and precise. We find no evidence that Viagra's introduction had any significant effect on any other outcome. As a result, we conclude that this lifestyle drug had a significant effect on short term lifestyle decisions (e.g., risky sexual encounters). We find no convincing evidence, though, that it affected deviant (e.g., sexual assault) or long run (e.g., natality, divorce) lifestyle decisions. Overall, in a back of the envelope cost benefit analysis, we find that the welfare impacts of Viagra with respect to our outcomes of interest are positive and large.

These results are important for several reasons. First, medical studies have attempted to determine if Viagra is associated with increased risk of STDs. Anupam et al. (2010) compares the STD rate of the group of older men taking ED medications with older men not taking ED medications. However, there are 
vast differences between these two groups and due to self-selection their estimates cannot be considered as causal. Our study is designed to pinpoint the causal percentage change of Viagra's availability on our variables of interest, something that the medical literature falls short on.

Second, the well-being of an aging population is an increasingly important topic given the vast demographic shifts occurring in the U.S., Europe and other industrializing countries. ${ }^{5}$ Medical innovations for the elderly increase the feasible choice set for their actions. Knowing precisely how this increased choice set affects socioeconomic decision making for older populations is therefore an important economic problem. The 15 years since Viagra's introduction offer a glimpse as to what economists might observe going forward as medical innovation increases. ${ }^{6}$

Third, there could be spillover and indirect effects of medical innovations on non-target groups. It is vital to understand the results for both males and females. Finding effects of Viagra on males demonstrates the existence of a direct effect. However, it important to understand how lifestyle drugs affect the agents who do not take the drugs but rather indirectly enjoy their benefits or suffer from their costs.

Fourth, the "Power of the Pill" articles have shown that innovation in medical technology has substantial impacts on many important economic choices made earlier in life by the targeted group (Goldin and Katz 2006 and Bailey 2002). Our paper is different because it the first to look at the effect of medical innovations for decisions made later in life, when individuals have more wealth and experience with decision making. We find that in the context of Viagra, if an individual does not have the ability to engage in sexual behavior and suddenly is given that ability, outcomes related to sexual behavior tend to be no different except for relatively low cost risky sexual decisions associated with instant gratification.

\footnotetext{
${ }^{5}$ In a different context, recent research finds larger concentrations of older populations can cause modest decreases in education spending and/or changes in the political economy equilibrium of different voting blocs (Harris et. al. 2001 and Levy 2005). The goal of the current paper, then, is to examine how one particular lifestyle drug targeted at the elderly population changes the aging population's socioeconomic decisions.

${ }^{6}$ Artificial organs, for example, are another major medical innovation which are currently being tested which could lead to major changes in the lifestyle decisions of the elderly and even young people.
} 
We find some evidence in this context, then, that self-control can be a challenge even for experienced decision makers.

The remainder of this paper is organized as follows: section two gives historical background on ED medication. Section three presents the econometric model. Section four presents results. Section five offers discussion and concluding remarks.

\section{Background and Data}

This section provides background about introduction of Viagra and the age composition of its users which are both necessary for discussion of the econometric model in section III. We also discuss the four variables of interest in this section, their relevance and the data used for analysis. For our variables of interest we collected separate datasets from different sources. As a result, the years for which data are available vary by outcome of interest.

Prior to the launch of Viagra (medical name Sildenafil) in April 1998, ED could only be treated with invasive methods involving injections, penile prosthesis, penis pumps or vascular reconstructive surgeries (Montague et al. 2005). The most common ED drug at the time was Aprostadil. Aprostadil is a penile suppository applied either into the urethra or injected into the penis about ten minutes before the erection is needed. Figure 1 below shows that while in March 1998 more than 900,000 units of Aprodastil were prescribed, one month later, in April 1998 this figure dramatically declined to 462,000 units to then continually decline to insignificant numbers today. ${ }^{7}$ The aphrodisiac Yohimbine, a sexual stimulant, experienced even more drastic declines.

This dramatic drop in medication sales can be clearly explained with the approval of Sildenafil by the Food and Drug Administration (FDA), becoming the first oral medication to treat ED, sold under the brand name Viagra starting in April of 1998. The new drug was celebrated in the press and public media as revolutionizing the sexual behavior of the elderly population. The New York Times, for example, in the

\footnotetext{
${ }^{7}$ ED medication data were purchased from IMS Health.
} 
year 1998 featured over 193 articles on Viagra. ${ }^{8}$ Viagra was advertised directly to consumers on U.S. on TV, famously being endorsed by sport stars like soccer player Pelé and former U.S. Senator Bob Dole. Viagra was voted the "word of the year" in both Germany and in the USA. Hence, many of the former customers of the drugs Aprodastil or Yohimbine immediately started taking Viagra. Moreover, many new patients must have adopted Viagra, as evidenced by Figure 2, which shows shipments to pharmacies for Viagra, Aprodastil and Yohimbine. Figure 2 demonstrates that simultaneously with the drop of the former ED drugs, in April 1998 ED drugs experienced an unprecedented consumption level due to the launch of Viagra selling over 14 million units. The figure shows that Aprodastil and Yohimbine played an insignificant role whereas Viagra dominated the market after its introduction.

\section{Data on Viagra Users}

An important factor to consider when determining the effects of the release of Viagra are the demographic characteristics of the drug's user. To identify demographic information of Viagra users, we collected data from the Prescribed Medicine File from the Household Component from a U.S. Department of Health and Human Services database called the Medical Expenditure Panel Survey (MEPS). ${ }^{9}$ It is a collection of results from nationally representative surveys that are distributed to families, individuals, medical providers, and employers throughout the United States. From $1998-2001^{10}$, MEPS collected data on various demographic characteristics of a random subsample of 158 Viagra users. We present summary statistics of this survey in this subsection.

Figure 3 shows the age distribution of Viagra users. The average Viagra user is 57 years old. The youngest participant in the survey was at 18 years, while the oldest was at 87 years of age. Overall, the distribution of ages appears fairly normal. Specifically, almost $90 \%$ of Viagra users in the survey are 45 years of age and older. Due to this age distribution, we establish the treatment group in our analysis as

${ }^{8}$ Titles for these articles included The Nation: Thanks a Bunch, Viagra and The Pill That Revived Sex, Or at Least Talking About It.

${ }^{9}$ These data are stored in the yearly Prescribed Medicine Files at http://www.meps.ahrq.gov/mepsweb/.

${ }^{10}$ We also collected the same information from MEPS for 2005-2007 and found that the age composition of Viagra users stayed roughly constant over time. That data is available from the authors upon request. 
individuals aged 45 and above and the control individuals 25-40. ${ }^{11}$ We drop individuals between the ages

41-44. We view this age category as neither in the treatment nor control as some of these individuals may be prescribed Viagra, but not in the concentrations of males aged 45 or over. For a different reason, we drop the 18-24 age group: sexual activity of the 18-24 age group is in all likelihood a poor control for people aged 45 and above relative to individuals aged 25-40. For example, the 25-40 age demographic has marriage rates much closer to the above 45 age group than 18-24 year olds.

\section{Data on Variables of Interest}

We examine how Viagra's introduction affects four different variables of interest. First we examine how Viagra affected gonorrhea rates in the drug's target population (e.g., males age 45 and above). ${ }^{12}$ STDs are of interest because it studies the drug's capacity to impact risky behavior associated with instant gratification. ${ }^{13}$ If Viagra did affect STDs, it is reasonable to expect that gonorrhea rates would be the clearest example: it is one of the most common STDs as it is a bacterial infection that can easily be transmitted by fluids. We examine gonorrhea rates for men of age 45 and above, but also for women. ${ }^{14}$ It

11 There are some media reports that recreational Viagra usage increased in younger men in the 2000s (http://usatoday30.usatoday.com/news/health/2001-03-21-viagra-abuse.htm). This implies that our estimates are lower bounds for the effect of Viagra on the treatment group if Viagra also had effects on the control group.

${ }^{12}$ To transfer the raw data of levels into age cohort-by-state and cohort-by-county rates, we use the Intercensal Estimates of the Resident Population by the U.S. Census Bureau, Population Division.

${ }^{13}$ Anupam et al. (2010) is one relevant study from the medical literature which relates STD rates of Viagra users to non-users. Anupam et al. (2010) does not use the approval of the drug as part of the identification technique. As a result, their "treated" population does not reflect the treatment group isolated with our identification strategy. The contribution of our study, then, is that it presents the first empirical paper that does document the causal relationship between ED medications and STD rates among the elderly, using the most comprehensive dataset collected for the U.S. In fact Anupam et al. (2010) suggest that a study such as ours, where STDs are compared prior and post the introduction of Viagra, should be performed. The medical literature further descriptively outlines some differences between ED users and non-users and we list these findings here: due to some combination of reduced fertility rates and preferences, elderly are up to one sixth less likely to use condoms than people in their twenties and one fifth as likely to be tested to STDs (Lindau et al. (2006), Patel et al. (2003) and Stall and Catania (1994)). To that end, primary care physicians are less likely to discuss STD prevention with older patients (see Skiest and Keiser, 1997). However, ED drugs users report having both more recent sexual partners and higher STD rates than non-users (see Paul et al. (2005) and Swearingen and Klansner (2005)). Although direct data does not exist, these findings imply that if older individuals use Viagra, they both have more unprotected sex with more sexual partners than older individuals who don't use Viagra. As a result, there is reason to believe that the introduction of Viagra led to a change in sexual behavior of people who took it. That is not to say there was not self-selection in which individuals choose to take Viagra but it is plausible that even with self-selection changes in sexual behavior are feasible. Unfortunately, due to a lack of data, more precise empirical statements are not possible.

${ }^{14}$ We collected data for chlamydia but that data series begins in 1996. Also, there was a significant improvement of Chlamydia screening which occurred during the study period (Gaydos et al. 2004). This partially explains a dramatic increase in chlamydia diagnoses over the sample period. Further, there was a change in public health policy which suggested that younger women be tested significantly more over this time period (Meyers et. al. 2004). As a result, there was a dramatic rise in chlamydia rates 
is important to understand how lifestyle drugs affect the agents who do not take the drug directly but rather indirectly enjoy their benefits or suffer from their costs. We obtained state level gonorrhea infection rate data by age and gender via email exchange from the Center for Disease Control. These data are available from the authors upon request.

Second, we test for how Viagra's introduction affects natality rates in the target population. This is a variable of interest because it highlights the drug's capacity to correct a physical disorder and the resulting impact on immediate family planning decisions. Viagra makes conceiving a child much less costly for the target population (males with ED). Therefore, natality rates could increase upon Viagra's introduction because couples who previously had physical impediments to conception would now be better enabled to conceive. ${ }^{15}$ State level natality data by father's age are drawn from the Center of Disease Control Vital Statistics. We define natality rates as the as number of newborns by fathers in age category $j$ in state $k$ divided by 100,000 men in age category $j$ in state $k$.

Third, we examine how Viagra's introduction affects criminal sexual activity. This is an important variable due to the magnitude of consequences for victims. It is possible that the publicity in the public media about Viagra and sex of elderly changed the sexual crime behavior of the elderly population. Hence, whether there has been an increase in such arrests in the United States since the release of Viagra, and if so amongst what age groups, is a relevant question. We collected data for (i) sex offenses arrests (that excludes forcible rapes) and (ii) forcible rape arrests in the U.S. by suspect's sex and age group. Sexual offenses includes the following crime subcategories: adultery/fornication, incest, buggery, indecent exposure, seduction and indecent liberties, sodomy or crimes against nature, statutory rape (not forced), and any attempts of the stated categories. ${ }^{16}$ County level arrests for sexual offense and rape

observed in the control group during this time period. Disentangling these last two effects from the Viagra effect is challenging. As a result, we do not include chlamydia in the analysis.

15 As noted above, we consider family planning generally as natality rates are a function of both planned and unplanned pregnancies.

${ }^{16}$ Sex solicitation rates are also not included in this category but in a "catch all" category that includes many other arrests not prevalent to this research. Solicitation rates may be of interest but are only recorded at the local level and time restraints do not allow us to acquire these rates. 
statistics are collected from the Uniform Crime Reports of the National Archive of Criminal Justice Data for almost 900 US counties.

Lastly, we test for Viagra's effect on divorce rates. This outcome highlights the importance of this particular medical innovation on the household production function and is also a long run planned decision. Viagra is a lifestyle drug that enables increased coital capacity for its users. If the relative benefit of getting married, staying in a marriage, or getting divorced is asymmetrically affected by Viagra then we would expect a significant effect of Viagra's introduction on marriage market in the treatment group. To test this hypothesis, divorce and marriage data were compiled using the Current Population Survey (CPS) of the Bureau of Census for the Bureau of Labor Statistics. This dataset is a time series of repeated cross-sectional draws of individuals in the US population.

\section{Econometric Model}

We estimate several econometric models to identify the causal effect of the introduction of Viagra on several outcomes of interest for men and women middle aged and older. Specifically, we estimate the drug's effect on rates of a sexually transmitted disease (gonorrhea), natality rates and sexual offenses rates including rape, and divorce rate. We use state level data for gonorrhea and natality, county-level data for crime and individual level data for divorce. ${ }^{17}$ We are forced to use state level data in some cases since, to our knowledge, no more granular level data exists.

For every variable of interest, our preferred econometric model uses a difference-in-difference estimator. Specifically, we estimate least squares and Poisson models with the following specification:

$y_{\text {sgt }}=h\left(\alpha+\mu_{s}+\right.$ trend $\left.+1\{g \geq 45\} \delta+1\{t \geq 1999\} \gamma+1\{g \geq 45\} 1\{t \geq 1999\} \beta+\varepsilon_{\text {sgt }}\right)$.

\footnotetext{
${ }^{17}$ In some cases we aggregate to the state level in order to include rural counties with few observations.
} 
In equation (1), $s$ indexes a location (state or county), $g$ indexes an age group and $t$ the year of observation. We allow for state or county fixed effects, $\mu_{s}$. When the data dictate, we include a linear time trend takes the value of one for observations in the first year of our dataset and $n$ for observations in the $n^{\text {th }}$ year of data. The function $h($ ) indicates that we sometimes estimate (1) as a semi-logarithmic model and sometimes as a Poisson model. We estimate the difference in outcomes for the control group for the post-1998 period relative to the pre-1999 period, $\gamma$, and the fixed effect of being in the target age group for Viagra, $\delta$. The main coefficient of interest is $\beta$ which indicates the change in outcome variable of interest for the treatment group attributable to the approval and sale of Viagra. The differences-indifferences identification strategy assumes that in the absence of treatment, the outcome variable of both the treatment and control groups would have evolved the same over time. We cluster standard errors at the state level to account for serial correlation within a state. Further all county data regressions are clustered by state which also accounts for the potential of spatial correlation within each state.

We estimate equation (1) using two methods. First, estimated by 'least squares', we put the outcome variables of interest in log rates. While log rates are useful for ease of interpretation, it is problematic for us in some cases: in our data we observe some years with zero rates in some age groups for certain variables of interest, especially in lower population states and counties. ${ }^{18}$ Taking the log of these rates leads to dropped observations and severe non-linearity around zero rates. We address this by trimming our datasets in the log rate specification so that no state or county with fewer than 10 observed outcomes are ever observed. For example, if a particular state ever has fewer than 10 observed cases of gonorrhea in either the treatment or control group we trim that state from the dataset. We find qualitatively similar results when using other trimming rules.

Second, in addition to estimating equation (1) using OLS and log rates, we also use a Poisson regressions with standard errors clustered by state. This is a natural setting for a Poisson regression since our dependent variables are count data (e.g., number of gonorrhea cases, number of births). This specification

\footnotetext{
${ }^{18}$ For example, in Wyoming there are no recorded sexual assaults for males older than 45.
} 
affords us the opportunity to use all of our data, as opposed to dropping some observations due to our trimming rule.

The key identifying assumption in our paper is the timing of treatment. Viagra was first sold commercially in mid-April 1998. We take 1999 to be the starting date of treatment for three reasons. First it is the first complete year that Viagra was legal. Second, our aim is to identify long run effects. Three, any learning about the drug was likely to have occurred in the second half of 1998. In any case, the qualitative results are robust to allowing the treatment date to start in 1998.

In interpreting our results, we want to stress caution in identifying causal long run impacts of Viagra due to some drawbacks of our data. First, we do not observe a panel dataset on both an individual's sexual activity and Viagra usage over time. Therefore, our results are market level outcomes. From a policy perspective, though, market level outcomes are the effects of interest since any public policy targeted toward lifestyle drugs would operate at the market level. Second, we did not conduct a randomized controlled trial, which would have been ideal for assessing the direct link between ED drug use and our variables of interest. Third, the timing of Viagra's availability was uniform in all 50 states. This eliminates cross-sectional variation in the timing of treatment as a source of identification in our analysis. As with any differences-in-differences approach, then, if the timing of treatment is correlated with any other event which affected the outcome of interest, it will bias our estimates. ${ }^{19}$ As a result, we urge further study with individual level panel data. Fourth, although our collected CDC, CPS and crime data reports the universe of all reported individuals in the US, the prevalence of some outcome variables is still low and precludes a highly powered analysis at the individual level. More generally, from a policy perspective further work may better characterize those users of ED drugs who are at highest risk for an STD. For example, screening, whether in the form of brief conversations or formal STD testing, would be most effective if targeted toward those at highest risk.

\footnotetext{
${ }^{19}$ For example, we cannot separately identify the role of media coverage of Viagra or advertising for Viagra directly affected the variables of interest.
} 


\section{Results}

\section{Sexually Transmitted Diseases}

We estimate the model with state level data for both males and females by age cohort using the CDC dataset. Figure 4 displays the aggregated data for gonorrhea rates by age group and sex. Due to differing levels across the two age cohorts the plot has different y-axes with the treatment group (e.g., older males) on the left y-axis and the control group on the right y-axis. Panel (a) in Figure 4 shows that gonorrhea rates increased substantially after 1999 for elderly males peaking in 2007 at $40 \%$ above of their 1999 levels. In comparison, the control group (age 25 to 40) saw only a slight increase. It is possible that some of the increase in the control group's rates may be transmission of gonorrhea from older to younger cohorts over time. As a result, then, our DD estimates (comparing the $40 \%$ increase relative to the marginal increase) are a lower bound of the effect of Viagra in the elderly population. Female gonorrhea rates are shown in panel (b). Here patterns are less clear. After Viagra's approval and sale gonorrhea rates in older women remain elevated while rates in young women decrease.

In Figure 4, two additional features are apparent. First, the early nineties experienced a substantial decline in the STD rates. This decline coincides with a time period of increased caution and educational campaigns to curb HIV infections in the U.S. (Health and Vital Statistics 2010). Starting in 1998 and 1999, with the introduction of Viagra, the age group trends reverse, with the elderly group showing striking increases of over $40 \%$ for males by $2007 .{ }^{20}$

Finally, Figure 4 shows a significant effect of the great recession after 2007. As the great recession affected accumulated wealth through the stock market and housing stock savings, it appears that the

\footnotetext{
${ }^{20}$ It is important to note, though, that STD rates did not immediately increase in the older cohort in 1998, but rather the rate of growth of STD infections increased. We see two potential reasons for this. First, bacteria need time to diffuse in the network of sexual partners through unsafe sexual encounters. The more people carry an STD the higher the probability of infection. Second, the composition of Viagra users could have changed over time, even if the age of distribution of Viagra users stays constant. For example, there could have initially been a social stigma associated with Viagra so that it was not accepted in casual situations. Conversely, it could have been prescribed more initially to couples in a long term relationship. Unfortunately, there is no dataset we are aware of that is a repeated cross section of Viagra users over time that could help us answer this more precisely.
} 
elderly group is more responsive to this wealth effect compared to the younger age cohort. ${ }^{21}$ We will return to this phenomenon when analyzing the natality data below.

Estimation results are shown in Tables 1 and 2 for males and females respectively. In these and all subsequent tables we present several versions of the econometric model and all our tables take the following form unless otherwise stated: all least squares specifications use log of rates as the dependent variable and progressively add more fixed effects and a linear time trend to control for the time varying effects. Because of using log rates, each of our OLS specifications trims the sample as described above (drops state/counties ever reporting fewer than 10 occurrences of the outcome variable). Our most flexible specification in log rates is column (3) which includes a linear time trend and state fixed effects. Columns (4) and (5) show results from estimating the Poisson model on the subset of the trimmed data (column (4)) that is used in the log rates specification and the full (untrimmed) dataset in column (5). The last two columns limit the entire sample so that only the years closest to the introduction of Viagra (1995-2005) are used in the analysis. We view the results from columns (6) and (7) as a robustness check to verify that the estimated effect of Viagra on our variables of interest is not being driven by data many years before or after Viagra's availability. For each variable of interest we also include additional robustness checks in the appendix that cut the sample differently. Our main treatment effect estimate of interest is the top row corresponding to $\beta$ of equation (1) labeled as "Viagra" in each table.

Table 1 displays the regression results for male gonorrhea rates as the left hand side variable. Gonorrhea rates in the older population of men unambiguously increases by between $15-28 \% .^{22}$ Estimates are somewhat smaller when the entire dataset is used in the Poisson specifications (5) and (7) compared the corresponding least squares specifications (4) and (6). For both the Poisson and OLS regression specifications, the estimated treatment effect of Viagra is overall consistent conditional on the number of

\footnotetext{
${ }^{21}$ This could also be the result of decreased medical care due to the recession and therefore missed diagnoses. Generally, the goal of this paper is not to attribute STD rates to business cycles so we leave this question to future research.

${ }^{22}$ Given that we find Gonorrhea rates increase for older men relative to younger men, there is the question of what percentage was due to increased infidelity of married men versus increased sexually activity of single men. Our data do not let us address this interesting question directly.
} 
years being used in the analysis being constant, i.e. excluding the years of the highest STD difference in 2006 and 2007 drops the estimated treatment effect from 23\% in column (5) to 15\% in column (7). The appendix further provides estimates on different time windows and shows that across all specifications the Poisson treatment effects range from $13 \%$ to $24 \%$.

Table 2 shows the same estimation results for females. It is important to note that in these specifications for females, our estimates are lower bounds since older infected men could have transmitted gonorrhea to younger women. Overall, we find only very weak evidence of an effect for females. In the Poisson regressions column (4) (which include all years from 1990 to 2011, but trims the data to at least 10) we find a significant effect of Viagra's introduction on older female gonorrhea rate. Once we, however, estimate this via least squares (column (3), or use all data (column 5) this significant result disappears. In other specifications with the entire time series, the coefficient of interest has the expected sign but is imprecisely estimated. In the robustness check in which we include only a subset of the years, the effects tighten to be nearly zero.

\section{Natality Rates}

State level natality data by father's age cohort are drawn from the Center of Disease Control Vital Statistics and are shown in Figure 5. As stated above, we define natality rates as the as number of newborns by fathers in age category $j$ in state $k$ divided by 100,000 men in age category $j$ in state $k^{23}$ Figure 5 displays log natality rates by age group. Three notes on this data are in order. First, there is an obvious drop in natality rates from 2004-2006 for the treatment group. This is due to unfortunately missing data in the CDC dataset for the 55+ age group in some states. Second, for the control group, we see a pre-trend decline in the natality rate over the first years of the sample period followed by an increase which mirrors the older age group’s increase. Third, both groups' natality rates fall with the onset of the

\footnotetext{
${ }^{23}$ We lagged our births in the following way: Our births in 1999 are matched to Viagra availability in 1998 (which is ideal, given that Viagra became available on April $1^{\text {st }}$ )
} 
great recession in 2008. To address these three data issues, in the following regressions we systematically vary the time window of included years.

Table (3) shows regression results from the data displayed in Figure 5. Overall, we find no convincing evidence that Viagra had a significant effect on natality rates for men in Viagra's target population in our models. Using the entire dataset, in only two specifications is there a marginally significant (10\% level) decrease in natality rates for the treatment group. Panel (b) and (c) then further display the regression results for the years 1994 to 2003 as well as 1990 to 2007 and 1995 to 2005. In particular the data from 1994-2003 is used (i) to balance the length of the pre-Viagra and post-Viagra periods, (ii) eliminate the different pre-1994 trends and (iii) ensure that we have data for all age groups (as the dataset starts to become irregular in 2004). Across all these specifications, taken together, we find no convincing evidence that Viagra had a significant effect on natality rates for men in Viagra’s target population.

Although we fail to reject the null hypothesis that Viagra had a significant increase on birth rates for the treated group, the $95 \%$ of the estimated confidence interval for the Poisson regression with all data and a time trend is $(-.077, .015)$. This means that the largest possible increase Viagra could have caused is 1.5\%. We take this as evidence that even if Viagra were inducing additional births by older males, the rate is small. ${ }^{24}$

\section{Sexual Offenses and Rape}

We collected county level rape and sexual assault arrest data for male perpetrators by age group from the Uniform Crime Reports of the National Archive of Criminal Justice Data. Figure 6 shows the trends in rape and sexual assault in log rates by age group. Both panels show a significant downward trend in

\footnotetext{
${ }^{24}$ Given that older males fathering rates are only 201 births per 100,000 (while the rate is above 7400 per 100,000 in the 25-40 age cohort), the overall economic effect is not large, as it would account for an additional 3 births only per 100,000. If it were true, though, that Viagra had a significant and negative effect on natality rates, the maximum estimated effect size, $-7.7 \%$ (or 15 newborns per 100,000), is non-trivial.
} 
criminal activity. It is not immediately apparent from the figure that Viagra's approval and sale caused significantly higher sexually related reported criminal activity by the target population.

Table (4) shows the regression results for county level rape arrests over the entire dataset. The three simplest regression specifications find a significantly positive effect of Viagra and rape arrests. These effects, though, are eliminated when more flexible specifications are performed. In the two most flexible specifications, (5) and (7), we find insignificant effects of Viagra on rape arrests. We show in the appendix the same qualitative results when we balance the dataset around Viagra's introduction date.

Table (5) shows the regression results for county level sexual offense arrests over the entire dataset. We find similar results to those from rape: in the simplest specifications we find a positive and significant effect of Viagra on sexual offenses that is eliminated in more flexible specifications. As further shown in the appendix, when using a balanced dataset around Viagra's introduction these results stay insignificant. In sum, we find no strong evidence that Viagra affected rates of rape or sexual offenses for the target population of the drug.

Although we fail to reject the null hypothesis that Viagra had a significant increase on crime rates for the treated group, the 95\% of the estimated confidence interval for the Poisson regression with all data is ($.112, .026)$. This means that the largest possible increase Viagra could have caused in our econometric model is $2.6 \%$, or 88 rapes per year. Rapes by males over 45 were 1300 in 1998, which represents $18 \%$ of all total rapes between both age groups.

\section{Divorce Rates}

To test if Viagra had an effect on divorce rates we collected data from the Current Population Survey (CPS) of the Bureau of Census for the Bureau of Labor Statistics. This data is somewhat different than our other data in that the CPS is collected as a random subsample of the US population each year. The 
dataset has age and marital status for the years 1990 to 2008. The average sample size per year for males is 50,879 and for females is 35,242 .

Data showing divorce rates by age are displayed in Figure 7. The graph shows divorces per 1000 married households. For both age groups, there is a pre-trend before Viagra's approval in 1998. The average number of divorced households is roughly 135 and 123 per 1000 married households for the treatment and control respectively over the sample period. It is not clear from a visual inspection that there is any significant break in this pre-trend due to Viagra's introduction. There is a discrete drop in the divorce rate between 2000 and 2001 in the control group, but that drop is both more than two full years after Viagra’s introduction and coincides with a US recession in that year. We performed regressions for both male and female divorce rates by age cohort as above. Although we do not report the output in tables, we estimate the effect of Viagra on male divorce to be 2.01 but that estimate is insignificant (clustered standard error is 2.3). Noting that the divorce rate for men in the treatment group in 1999 is 140 per 1000, this represents a statistically insignificant change of roughly $1.4 \%$. Similarly, we perform the same specification for women and estimate a coefficient of .059 and that estimate is also insignificant (standard error is .053). Taken together, these estimates indicate that Viagra had no statistically significant effect in the marriage market.

While we find no effect on the aggregate divorce rate, it could still be that Viagra affected the age composition of divorces and marriages. Tables (6) and (7) address these possible effects. We collected three years of data (1989, 1997, and 2007) from the CPS in order to check for Viagra effects the age composition of marriage in the treatment group. The reason to start with 1989 is that we did not want to attribute long run trends occurring before 1997 to Viagra. We also stop the sample in 2007 to avoid any systematic interactions of marriage/divorce patterns by age due to the great recession. Table 6 shows a cross tab of average and standard deviation of age for all cohabitating married couples by male's age. Consistent with intuition, younger people are marrying later. The population of older married males 
appears to be getting younger. This trend started before Viagra's introduction. The average age of females married to men 45 or older has stayed roughly constant.

Breaking the data down further, we calculate percentiles of wife's age conditional on having a husband aged 45 or more in Table 2. The table shows that there is no significant effect in the bottom half of the distribution after the introduction of Viagra that breaks from pre-trends. We take this as further evidence that any effects occurring the marriage market due to Viagra's introduction are likely to be second order. Taking the results of Table 1 and 2 together shows that the age spread between older males and their spouses is unaffected by the introduction of Viagra.

In sum, although we fail to reject the null hypothesis that Viagra had a significant increase on divorce rates for the treated group, the $95 \%$ of the estimated confidence interval for the percentage change in divorce rates is $(-.018, .047)$. This means that the largest possible increase Viagra could have caused in our econometric model is $4.7 \%$ or a decrease of $1.8 \%$. There are reasonable arguments for Viagra leading to an increase in divorce (Viagra makes being single relatively more attractive) or a decrease in divorce (Viagra improves marriages). Either percentage change, though, is dominated by long run trends for the older age cohort.

\section{Welfare}

Our results can inform a rudimentary welfare calculation of the effect of Viagra on the target population. For four variables of interest—natality, divorce and sex crimes and age spread—we find no evidence that Viagra had a statistically significant effect on the target population. We find that Viagra's introduction increased gonorrhea rates $15-28 \%$ for both men and women older than 45 . According to the CDC, the average gonorrhea rate in 2011 in the 45-55 age group ranged from 20.8-30.3 per 100,000 and 6.0-9.7 for 55-65 with negligible rates for ages $65+.{ }^{25}$ Taking the upper bounds for both of the gonorrhea rate

\footnotetext{
${ }^{25}$ http://www.cdc.gov/std/stats11/tables/21.htm. Last retrieved October 17, 2013.
} 
increases due to Viagra it implies that Viagra is responsible for at most an additional 4381 cases of gonorrhea per year in the target population. ${ }^{26}$ Gonorrhea is commonly treated with Cefixime, which has inexpensive generic versions for no more than $\$ 40$. Therefore, this yearly negative cost due to Viagra’s introduction is on the order of $\$ 140,000$. This number is clearly a lower bound on cost, though, given the physical and psychic costs of gonorrhea. However, the number is orders of magnitude lower than annual sales of Viagra, which is a lower bound for consumer value associated with its use. As a result, we conclude that a back of the envelope welfare calculation finds that Viagra's introduction led to an overall welfare increase.

\section{Conclusions}

We use the introduction of a well-publicized and heavily prescribed lifestyle drug, Viagra, to test how that drug affects outcomes for the target age cohort. We are studying four types of lifestyle choices of economic importance: enabled risky behavior associated with instant gratification (STD rates), enabled child bearing and family planning decisions (natality and divorce), and enabled criminal behavior (sexual assault and rape). We find evidence that the drug increased STDs in the target population but that no other variable of interest was affected. As a result, we find that this particular medical innovation targeted toward older age cohorts only led to changes in short term decision making rather than long run decision making. Overall, in a back of the envelope cost benefit analysis, we find that the welfare impacts of Viagra with respect to our outcomes of interest are positive and large.

These results have important implications for the economics literature. First, as the population ages, more resources will be invested in improving the elderly's quality of life by the development of medical innovations. As other new groundbreaking medical innovations are introduced, our results imply that there might not be necessarily substantial changes economic decisions with long term impacts by the

26 Average gonorrhea rates by age from the CDC and population by age data from the census from 2011, http://www.census.gov/population/age/data/2011comp.html. Last retrieved October 17, 2013. 
elderly. Second, these results contribute to a large economic literature on how endowments and wealth influence decision making since older individuals have, on average, more wealth than younger cohorts (Kahneman et. al. 1991 and Rabin 1998). We find that Viagra affected relatively low cost risky decisions associated with instant gratification only. This points to self-control problems, even for experienced decision makers. These questions could be important avenues for future research to better understand decisions in an aging population.

\section{References}

Anupam B. Jena, Dana P. Goldman, Amee Kamdar, Darius N. Lakdawalla, Yang Lu; "Sexually Transmitted Diseases Among Users of Erectile Dysfunction Drugs: Analysis of Claims Data.” Annals of Internal Medicine. 153(1):1-7.

Bailey, M. (2006). “More Power to the Pill: The Impact of Contraceptive Freedom on Women's Life Cycle Labor Supply,” The Quarterly Journal of Economics. 121(1): 289-320.

Blundell, R., C. Meghir, M.C. Dias, and J. Van Reenen (2004). "Evaluating the Employment Impact of a Mandatory Job Search Program” Journal of the European Economic Association. 2(4): 569-606.

Culter, D.M. (2007). “The Lifetime Costs and Benefits of Medical Technology” Journal of Health Economics. 26(6): 1081-1100.

Cutler, D.M. and McClellan M. (2001). “Is Technological Change in Medicine Worth It?” Health Affairs. 20: 11-29.

Goldin, C. and L. Katz (2002). "The Power of the Pill: Oral Contraceptives and Women's Career and Marriage Decisions,” Journal of Political Economy. 110(4): 730-770.

Gaydos, C. A., Theodore, M., Dalesio, N., Wood, B. J., \& Quinn, T. C. (2004). Comparison of three nucleic acid amplification tests for detection of Chlamydia trachomatis in urine specimens. Journal of clinical microbiology, 42(7), 3041-3045

Harris, A.R., W.N. Evans, R.M. Schwab (2001). “Education spending in an aging America,” Journal of Public Economics. 81: 449-472.

Health and Vital Statistics (2010). “Use of Contraception in the United States: 1982-2008." U.S. Department of Health and Human Services, Series 23, Number 29.

Kahneman, D., Knetsch, J.L., \& Thaler, R.H. (1991) “Anomalies: The Endowment Effect, Loss Aversion and Status Quo Bias” The Journal of Economic Perspectives. 5(1): 193-206.

Levy, G. (2005). “The Politics of Public Provision of Education,” Journal of Political Economy. 120(4): 1507-1534.

Lindau ST, Leitsch SA, Lundberg KL, Jerome J. 2006. “Older women's attitudes, behavior, and communication about sex and HIV: a community-based study.” Journal of Women's Health. 15:747-53. 
Meyers, D., Wolff, T., Gregory, K., Marion, L., Moyer, V., Nelson, H., ... \& Sawaya, G. F. (2008). USPSTF recommendations for STI screening. American family physician, 77(6), 819.

Montague, D.K., Jarow, J.P., Broderick, G.A., Dmochowski, R.R., Heaton, J.P., Lue, T.F., Milbank, A.J., Nehra, A., \& Sharlip, I.D. (2005). “The Management of Erectile Dysfunction: An AUA update.” Journal of Urology, 174(1), 230-239.

Patel D, Gillespie B, Foxman B. 2003. "Sexual behavior of older women: results of a random-digitdialing survey of 2,000 women in the United States.” Sexually Transmitted Diseases. 30:216-20.

Paul JP, Pollack L, Osmond D, Catania JA. 2005. "Viagra (sildenafil) use in a population-based sample of U.S. men who have sex with men.” Sexually Transmitted Diseases. 32:531-533.

Rabin, M. (1998) “Psychology and Economics” Journal of Economic Literature. 36(1): 11-46.

Skiest DJ, Keiser P. 1997. "Human immunodeficiency virus infection in patients older than 50 years. A survey of primary care physicians' beliefs, practices, and knowledge.” Archives of Family Medicine. 6:289-94.

Stall R, Catania J. 1994. "AIDS risk behaviors among late middle-aged and elderly Americans. The National AIDS Behavioral Surveys.” Archives of Internal Medicine. 154: 57-63.

Swearingen SG, Klausner JD. 2005. "Sildenafil use, sexual risk behavior, and risk for sexually transmitted diseases, including HIV infection.” American Journal of Medicine. 118: 571-577. 
TABLE 1: Impact of Viagra on Log Rate of Gonorrhea Cases 1990-2011: US Males

\begin{tabular}{|c|c|c|c|c|c|c|c|}
\hline & \multicolumn{5}{|c|}{ 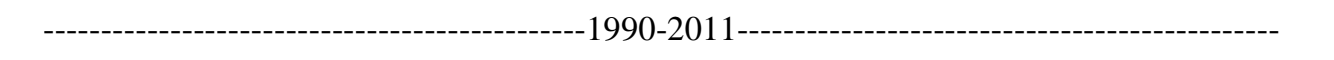 } & \multicolumn{2}{|c|}{-----------------1995-2005----------------- } \\
\hline & Least Squares & Least Squares & Least Squares & Poisson & Poisson & Least Squares & Poisson \\
\hline & (1) & (2) & (3) & (4) & (5) & (6) & (7) \\
\hline Viagra & $\begin{array}{c}0.281 \\
(0.044)^{* * *}\end{array}$ & $\begin{array}{l}0.281 \\
(0.044)^{* * *}\end{array}$ & $\begin{array}{l}0.281 \\
(0.044)^{* * *}\end{array}$ & $\begin{array}{l}0.274 \\
(0.053)^{* * *}\end{array}$ & $\begin{array}{l}0.229 \\
(0.064)^{* * *}\end{array}$ & $\begin{array}{l}0.169 \\
(0.046) * * *\end{array}$ & $\begin{array}{l}0.155 \\
(0.061)^{* *}\end{array}$ \\
\hline $45+$ & $\begin{array}{l}-3.887 \\
(0.065) * * *\end{array}$ & $\begin{array}{l}-3.887 \\
(0.066)^{* * *}\end{array}$ & $\begin{array}{l}-3.887 \\
(0.066)^{* * *}\end{array}$ & $\begin{array}{l}-3.896 \\
(0.051)^{* * *}\end{array}$ & $\begin{array}{l}-3.723 \\
(0.076)^{* * *}\end{array}$ & $\begin{array}{l}-3.761 \\
(0.068) * * *\end{array}$ & $\begin{array}{l}-3.660 \\
(0.078)^{* * *}\end{array}$ \\
\hline $\mathrm{t}>1998$ & $\begin{array}{l}-0.182 \\
(0.056) * * *\end{array}$ & $\begin{array}{l}-0.182 \\
(0.057)^{* * *}\end{array}$ & $\begin{array}{l}-0.013 \\
(0.049)\end{array}$ & $\begin{array}{c}0.024 \\
(0.035)\end{array}$ & $\begin{array}{c}0.027 \\
(0.036)\end{array}$ & $\begin{array}{l}-0.098 \\
(0.042) * *\end{array}$ & $\begin{array}{l}-0.031 \\
(0.039)\end{array}$ \\
\hline Linear trend & & & $\begin{array}{l}-0.015 \\
(0.004)^{* * *}\end{array}$ & $\begin{array}{l}-0.028 \\
(0.004)^{* * *}\end{array}$ & $\begin{array}{l}-0.022 \\
(0.007) * * *\end{array}$ & $\begin{array}{c}0.022 \\
(0.010)^{* *}\end{array}$ & $\begin{array}{c}0.010 \\
(0.010)\end{array}$ \\
\hline State FE & No & Yes & Yes & Yes & Yes & Yes & Yes \\
\hline Adjusted $R^{2}$ & 0.93 & 0.97 & 0.97 & . & . & 0.98 & . \\
\hline$R^{2}$ & 0.93 & 0.97 & 0.97 & 0.92 & 0.89 & 0.98 & 0.92 \\
\hline$N$ & 836 & 836 & 836 & 836 & 2242 & 418 & 1,122 \\
\hline
\end{tabular}

$* p<0.1 ; * * p<0.05$; *** $p<0.01$. All columns have standard errors clustered at the state level.

Least squares specifications drop 32 states that ever have less than 10 cases in a given age category in a given year.

Note that in 1999 there were 30,687 reported cases of gonorrhea in males 25-40 and 1,326 in males 45+. 
Table 2: Impact of Viagra on Log Rate of Gonorrhea Cases 1990-2011: US Females

\begin{tabular}{|c|c|c|c|c|c|c|c|}
\hline & \multicolumn{5}{|c|}{ 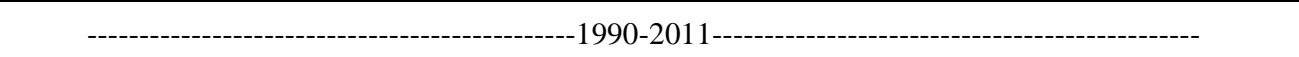 } & \multicolumn{2}{|c|}{------------------1995-2005--------------- } \\
\hline & Least Squares & Least Squares & Least Squares & Poisson & Poisson & Least Squares & Poisson \\
\hline & (1) & $(2)$ & (3) & (4) & (5) & (6) & (7) \\
\hline Viagra & $\begin{array}{c}0.077 \\
(0.046)\end{array}$ & $\begin{array}{c}0.077 \\
(0.046)\end{array}$ & $\begin{array}{c}0.077 \\
(0.047)\end{array}$ & $\begin{array}{l}0.146 \\
(0.059)^{* *}\end{array}$ & $\begin{array}{c}0.088 \\
(0.047) *\end{array}$ & $\begin{array}{c}0.016 \\
(0.037)\end{array}$ & $\begin{array}{c}0.008 \\
(0.039)\end{array}$ \\
\hline $45+$ & $\begin{array}{l}-2.306 \\
(0.042) * * *\end{array}$ & $\begin{array}{l}-2.306 \\
(0.043)^{* * *}\end{array}$ & $\begin{array}{l}-2.306 \\
(0.043) * * *\end{array}$ & $\begin{array}{l}-2.349 \\
(0.045) * * *\end{array}$ & $\begin{array}{l}-2.253 \\
(0.070) * * *\end{array}$ & $\begin{array}{l}-2.197 \\
(0.031)^{* * *}\end{array}$ & $\begin{array}{l}-2.155 \\
(0.059) * * *\end{array}$ \\
\hline $\mathrm{t}>1998$ & $\begin{array}{l}-0.388 \\
(0.063)^{* * *}\end{array}$ & $\begin{array}{l}-0.388 \\
(0.064)^{* * *}\end{array}$ & $\begin{array}{l}0.196 \\
(0.047)^{* * *}\end{array}$ & $\begin{array}{l}0.183 \\
(0.038)^{* * *}\end{array}$ & $\begin{array}{l}0.141 \\
(0.039)^{* * *}\end{array}$ & $\begin{array}{l}0.097 \\
(0.044)^{* *}\end{array}$ & $\begin{array}{c}0.049 \\
(0.047)\end{array}$ \\
\hline Linear trend & & & $\begin{array}{l}-0.053 \\
(0.005) * * *\end{array}$ & $\begin{array}{l}-0.062 \\
(0.004)^{* * *}\end{array}$ & $\begin{array}{l}-0.060 \\
(0.008)^{* * *}\end{array}$ & $\begin{array}{l}-0.023 \\
(0.010)^{* *}\end{array}$ & $\begin{array}{l}-0.027 \\
(0.010)^{* * *}\end{array}$ \\
\hline State FE & No & Yes & Yes & Yes & Yes & Yes & Yes \\
\hline Adjusted $R^{2}$ & 0.84 & 0.93 & 0.95 & . & . & 0.97 & . \\
\hline$R^{2}$ & 0.84 & 0.93 & 0.95 & 0.92 & 0.91 & 0.97 & 0.92 \\
\hline$N$ & 836 & 836 & 836 & 836 & 2,242 & 418 & 1,122 \\
\hline
\end{tabular}

$* p<0.1 ; * * p<0.05 ; * * * p<0.01$, all columns have standard errors clustered at the state level.

Least Squares specifications drop 32 states that ever have less than 10 cases in a given age category in a given year

Note that in 1999 there were 55,071 reported cases of gonorrhea in females 25-40 and 8,169 in females 45+ 
Table 3: Impact of Viagra on Rate of Births by age of US Male, 1990-2010

\begin{tabular}{|c|c|c|c|c|}
\hline & \multicolumn{4}{|c|}{------------------------------------1990-2010----------------------------------- } \\
\hline & Least Squares & Least Squares & Least Squares & Poisson \\
\hline & (1) & (2) & (3) & (4) \\
\hline Viagra & $\begin{array}{l}-0.028 \\
(0.022)\end{array}$ & $\begin{array}{l}-0.028 \\
(0.017) *\end{array}$ & $\begin{array}{l}-0.028 \\
(0.016)^{*}\end{array}$ & $\begin{array}{l}-0.031 \\
(0.023)\end{array}$ \\
\hline $45+$ & $\begin{array}{l}-3.745 \\
(0.016)^{* * *}\end{array}$ & $\begin{array}{l}-3.745 \\
(0.012)^{* * * *}\end{array}$ & $\begin{array}{l}-3.745 \\
(0.012)^{* * *}\end{array}$ & $\begin{array}{l}-3.704 \\
(0.017)^{* * *}\end{array}$ \\
\hline t>1998 & $\begin{array}{l}0.098 \\
(0.009)^{* * *}\end{array}$ & $\begin{array}{l}0.098 \\
(0.011)^{* * *}\end{array}$ & $\begin{array}{l}0.052 \\
(0.017)^{* * *}\end{array}$ & $\begin{array}{l}0.058 \\
(0.005)^{* * *}\end{array}$ \\
\hline Linear trend & & & $\begin{array}{c}0.004 \\
(0.001)^{* * *}\end{array}$ & $\begin{array}{c}0.004 \\
(0.001)^{* * *}\end{array}$ \\
\hline State FE & No & Yes & Yes & Yes \\
\hline Adjusted $R^{2}$ & 0.98 & 0.99 & 0.99 & 0.99 \\
\hline \multirow[t]{4}{*}{$N$} & 1,836 & 1,836 & 1,836 & 1,836 \\
\hline & \multicolumn{4}{|c|}{ 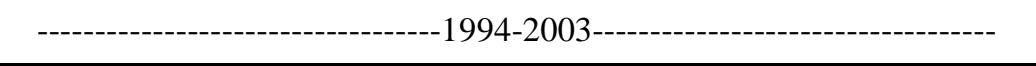 } \\
\hline & Least Squares & Least Squares & Least Squares & Poisson \\
\hline & (5) & (6) & (7) & (8) \\
\hline Viagra & $\begin{array}{l}-0.049 \\
(0.029)^{*}\end{array}$ & $\begin{array}{l}-0.049 \\
(0.022)^{* *}\end{array}$ & $\begin{array}{l}-0.049 \\
(0.022)^{* *}\end{array}$ & $\begin{array}{l}-0.049 \\
(0.030)\end{array}$ \\
\hline $45+$ & $\begin{array}{l}-3.707 \\
(0.021)^{* * *}\end{array}$ & $\begin{array}{l}-3.707 \\
(0.015)^{* * *}\end{array}$ & $\begin{array}{l}-3.707 \\
(0.015)^{* * *}\end{array}$ & $\begin{array}{l}-3.672 \\
(0.021)^{* * *}\end{array}$ \\
\hline $\mathrm{t}>1998$ & $\begin{array}{l}0.086 \\
(0.013)^{* * * *}\end{array}$ & $\begin{array}{l}0.086 \\
(0.015)^{* * * *}\end{array}$ & $\begin{array}{c}0.027 \\
(0.025)\end{array}$ & $\begin{array}{l}0.011 \\
(0.004)^{* * *}\end{array}$ \\
\hline Linear trend & & & $\begin{array}{l}0.012 \\
(0.004)^{* * *}\end{array}$ & $\begin{array}{l}0.015 \\
(0.001)^{* * *}\end{array}$ \\
\hline State FE & No & Yes & Yes & Yes \\
\hline Adjusted $R^{2}$ & 0.98 & 0.99 & 0.99 & 0.99 \\
\hline \multirow[t]{4}{*}{$N$} & 1,020 & 1,020 & 1,020 & 1,020 \\
\hline & \multicolumn{2}{|c|}{---------------1990-2007------------ } & \multicolumn{2}{|c|}{--------------1995-2005----------- } \\
\hline & Least Squares & Poisson & Least Squares & Poisson \\
\hline & (1) & (2) & (3) & (4) \\
\hline Viagra & $\begin{array}{l}-0.018 \\
(0.018)\end{array}$ & $\begin{array}{l}-0.023 \\
(0.026)\end{array}$ & $\begin{array}{l}-0.051 \\
(0.031)^{*}\end{array}$ & $\begin{array}{l}-0.049 \\
(0.032)\end{array}$ \\
\hline $45+$ & $\begin{array}{l}-3.745 \\
(0.012)^{* * *}\end{array}$ & $\begin{array}{l}-3.704 \\
(0.017)^{* * *}\end{array}$ & $\begin{array}{l}-3.705 \\
(0.017)^{* * *}\end{array}$ & $\begin{array}{l}-3.671 \\
(0.024)^{* * *}\end{array}$ \\
\hline $\mathrm{t}>1998$ & $\begin{array}{l}0.036 \\
(0.019)^{*}\end{array}$ & $\begin{array}{l}0.059 \\
(0.006)^{* * *}\end{array}$ & $\begin{array}{c}0.024 \\
(0.026)\end{array}$ & $\begin{array}{c}0.003 \\
(0.004)\end{array}$ \\
\hline Linear trend & $\begin{array}{l}0.006 \\
(0.002)^{* * *}\end{array}$ & $\begin{array}{l}0.003 \\
(0.001)^{* * *}\end{array}$ & $\begin{array}{c}0.013 \\
(0.004)^{* * *}\end{array}$ & $\begin{array}{l}0.018 \\
(0.001)^{* * *}\end{array}$ \\
\hline State FE & Yes & Yes & Yes & Yes \\
\hline Adjusted $R^{2}$ & 0.99 & 0.99 & 0.99 & 0.99 \\
\hline$R^{2}$ & 0.99 & 0.99 & 0.99 & 0.99 \\
\hline$N$ & 1,530 & 1,530 & 918 & 918 \\
\hline
\end{tabular}

$* p<0.1 ; * * p<0.05 ; * * * p<0.01$, all columns have standard errors clustered at the state level.

Least Squares regressions use log rates as left hand side variable. Poisson specifications use count data. 2003 is last year before missing data for 55+ age cohort's fatherhood data. 
TABLE 4: Impact of Viagra on log rate of rape arrests by US male population by county: 1994-2010

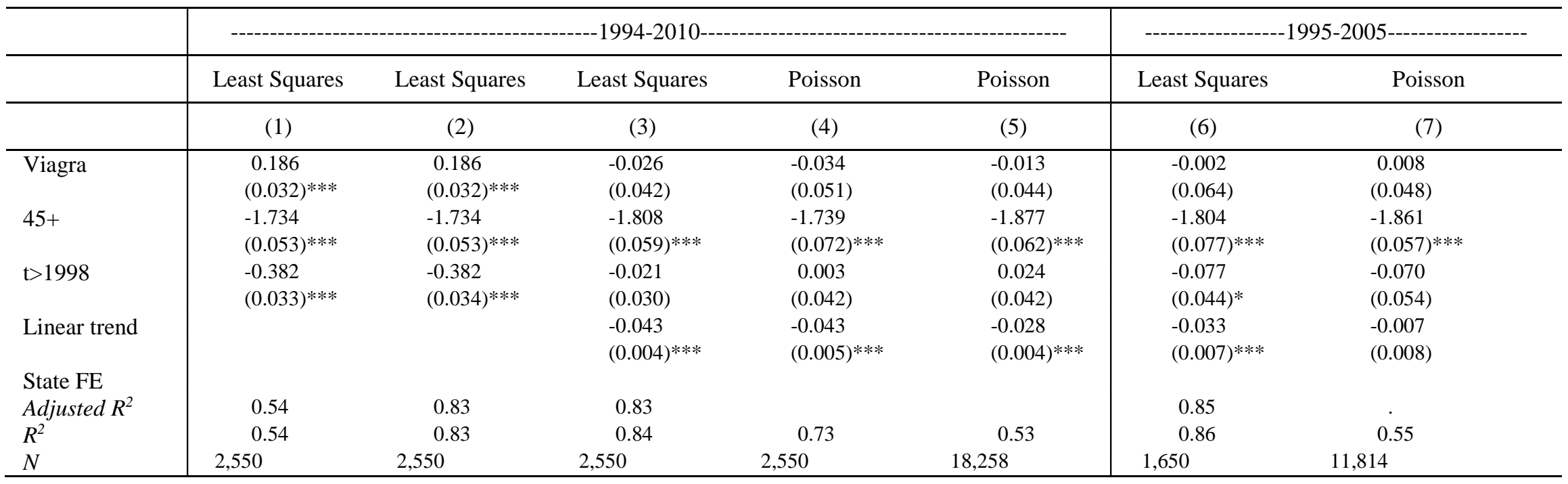

$* p<0.1 ; * * p<0.05 ; * * * p<0.01$, all columns have standard errors clustered at the state level.

Least Squares specifications drop 32 states that ever have less than 10 cases in a given age category in a given year 
TABLE 5: Impact of Viagra on log rate of sexual offense arrests of US males: 1994-2010

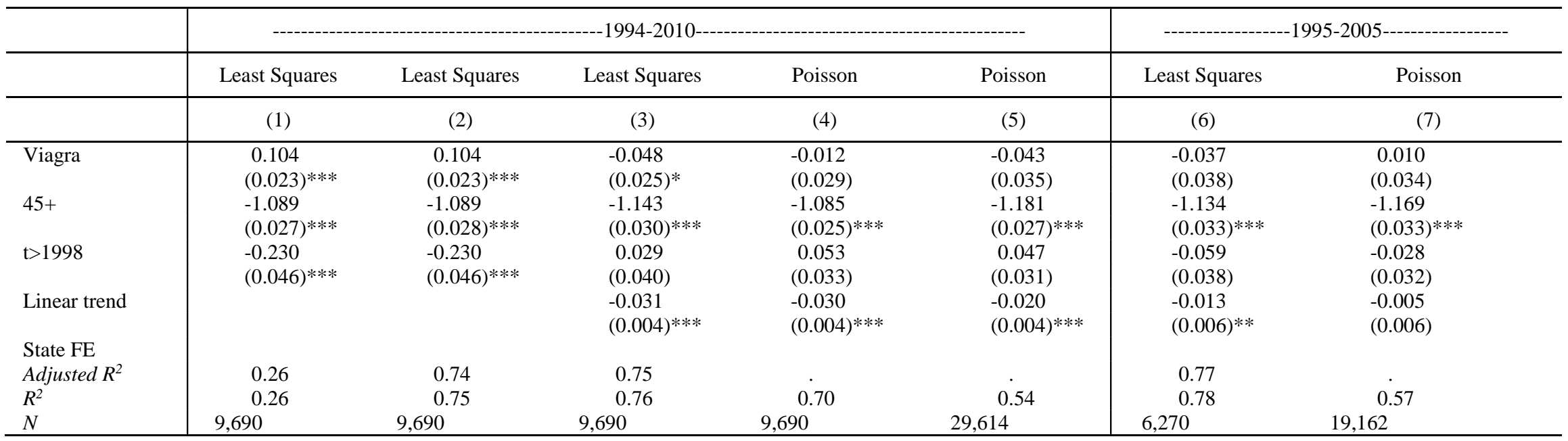

$* p<0.1 ; * * p<0.05 ; * * * p<0.01$, all columns have standard errors clustered at the state level.

Least Squares specifications drop 32 states that ever have less than 10 cases in a given age category in a given year 
TABLE 6: Mean Age of Married Female by Husband's Age

\begin{tabular}{ccccc} 
& \multicolumn{2}{c}{ Male 25-40 } & \multicolumn{2}{c}{ Male 45+ } \\
Year & Male & Female & Male & Female \\
\hline \multirow{2}{*}{1989} & 33.15 & 31.62 & 60.38 & 56.48 \\
& 4.36 & 5.24 & 10.56 & 11.57 \\
& & & & \\
1997 & 33.72 & 32.66 & 59.92 & 56.11 \\
& 4.34 & 5.71 & 11.02 & 11.87 \\
& & & & \\
& 33.71 & 32.85 & 59.64 & 56.33 \\
& 4.34 & 5.93 & 10.55 & 11.32 \\
\hline
\end{tabular}

1989 data: $n=137,108$ (25-40) and 191,092 (45+).

1997 data: $n=98,765$ (25-40) and 168,596 (45+).

2007 data: $n=90,611$ (25-40) and 215,407 (45+).

All data from CPS IPUMS

TABLE 7: Age Distribution of Married Females Conditional on Husband 45+

\begin{tabular}{|c|c|c|c|c|c|}
\hline \multirow[b]{2}{*}{ Year } & \multicolumn{5}{|c|}{ Percentile } \\
\hline & $1 \%$ & $5 \%$ & $10 \%$ & $25 \%$ & $50 \%$ \\
\hline 1989 & 31 & 39 & 43 & 47 & 56 \\
\hline 1997 & 32 & 39 & 43 & 47 & 54 \\
\hline 2007 & 33 & 40 & 43 & 48 & 55 \\
\hline
\end{tabular}




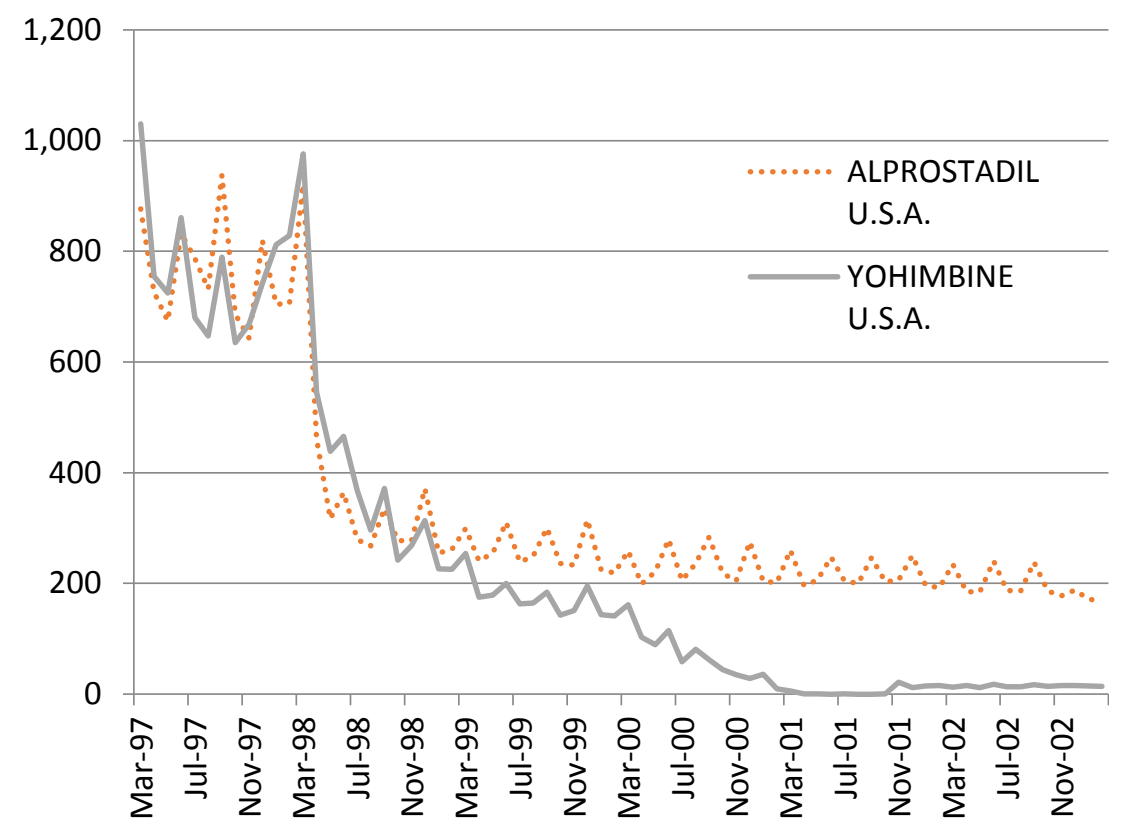

Figure 1: Prescribed units (in thousands) sold of Aprodastil and Yohimbine March 1997 to February 2003 in the U.S.A. 


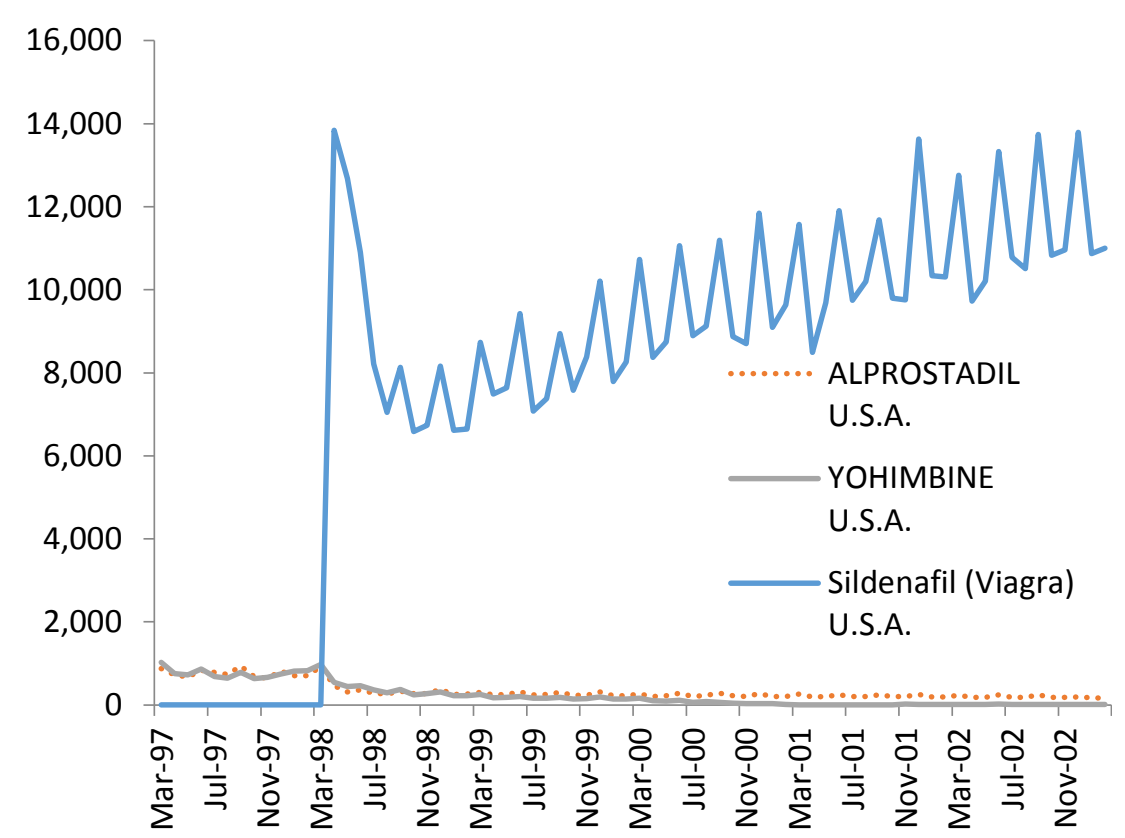

Figure 2: Prescribed Units (in Thousands) sold of all ED related medications, Mar 1997 to Feb 2005, USA 


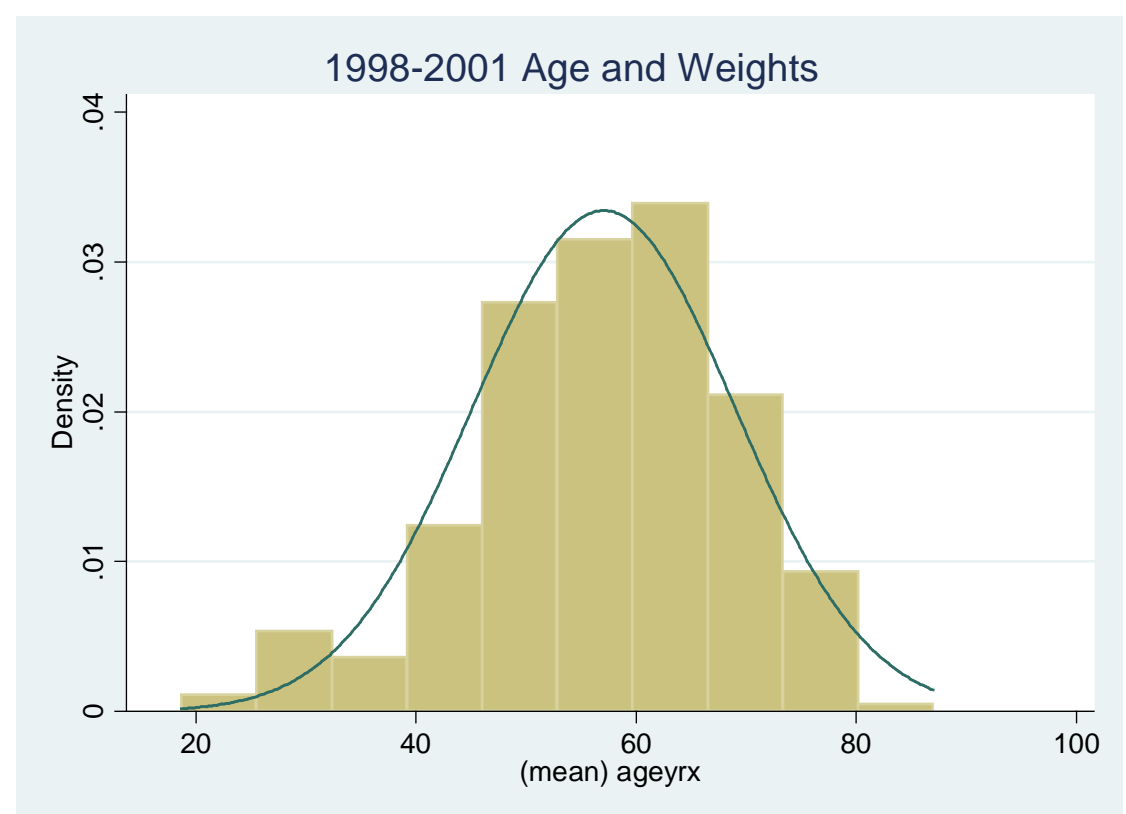

Figure 3: Histogram of US Viagra users by age. Data from MEPS survey of Viagra users from 1998-2001. 


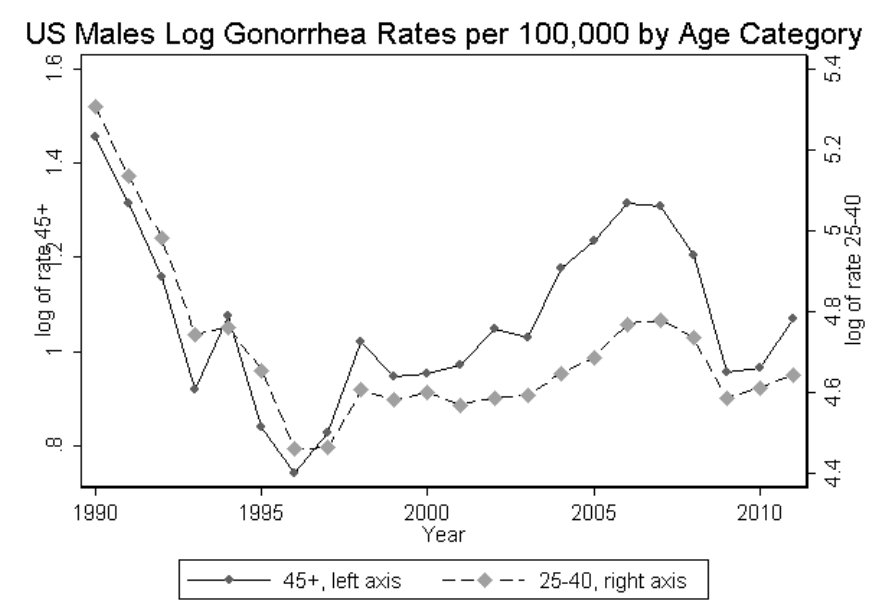

(a) Male gonorrhea rates by age group

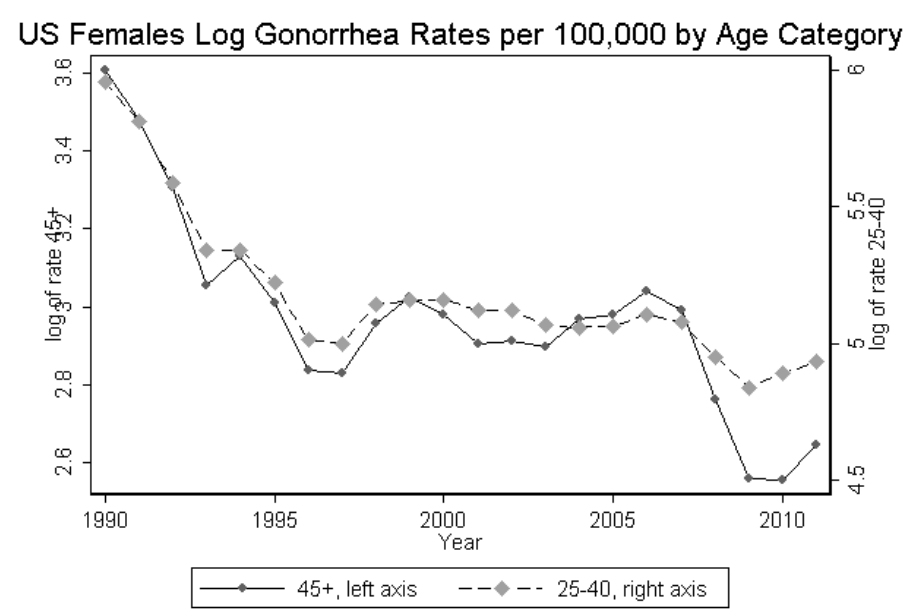

(b) Female gonorrhea rates by age group

Figure 4: Gonorrhea log rates by age and sex. State level population weighted data shown.

Data obtained from CDC. Left axis corresponds to older cohort and Right axis the younger age group. 


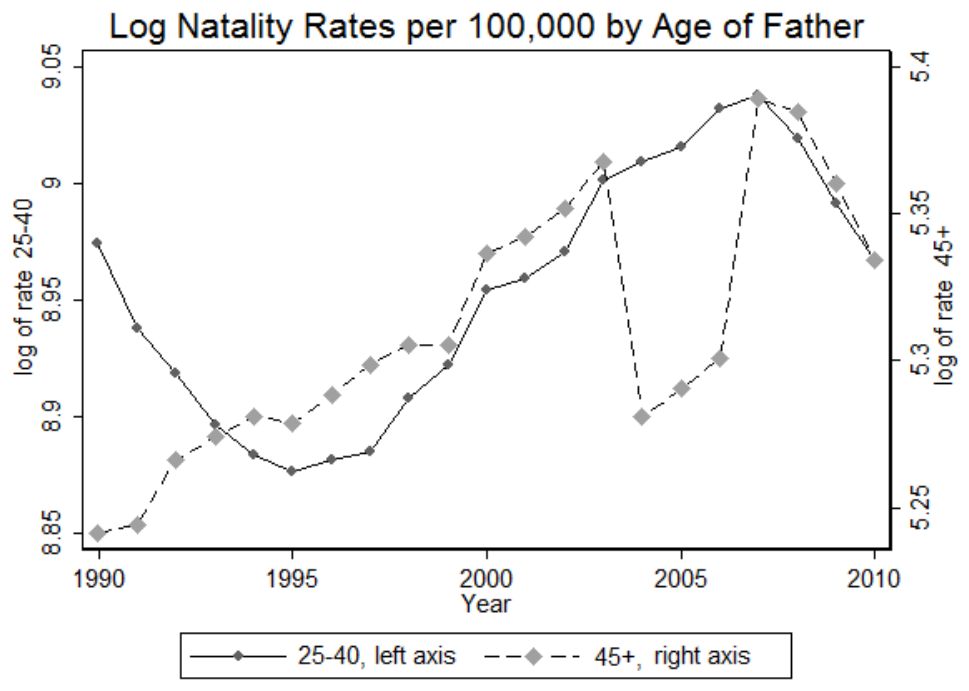

Figure 5: Natality log rates by father's age.

State level natality data are drawn from the Center of Disease Control Vital Statistics. Natality rate defined as the number of newborns by fathers in age category $j$ in state $k$ divided by 100,000 men in age category $j$ in state $k$. 


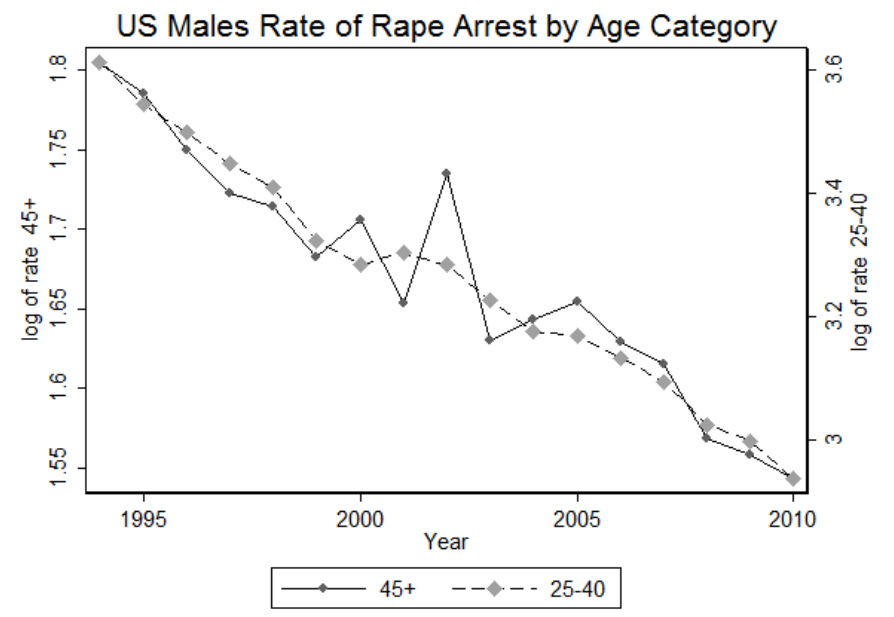

(a) County level log rate data for rape.

US Males Rate of Sexual Offense by Age Catergory

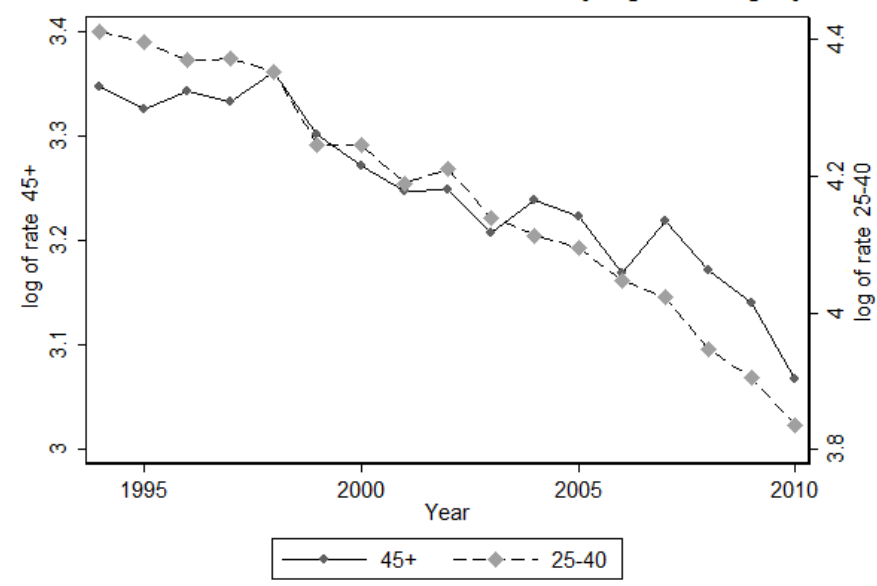

(b) County level log rate data for Sexual Offense.

Figure 6: Rape and sexual assault data.

The data are collected from the Uniform Crime Reports of the National Archive of Criminal Justice Data. Sexual Offenses include adultery/fornication, incest, buggery, indecent exposure, seduction and indecent liberties, sodomy or crimes against nature, statutory rape (not forced) 


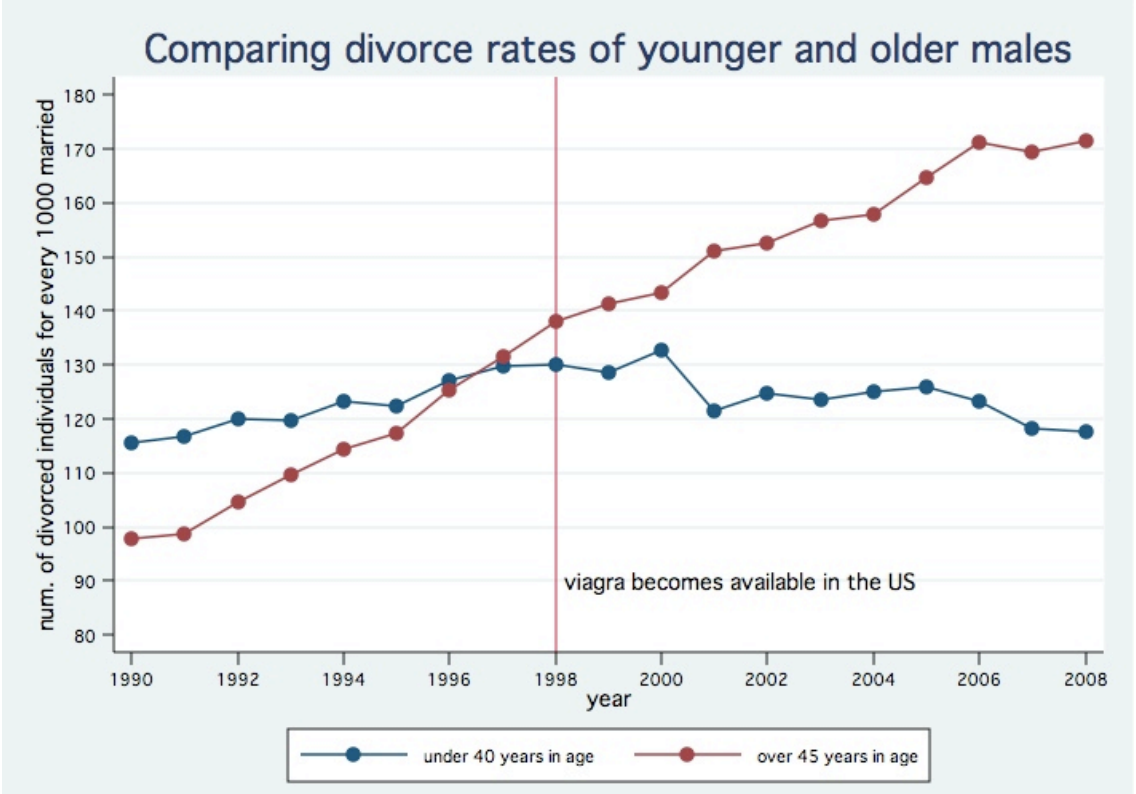

Figure 7: Divorces per 1000 married households for males. Red vertical line is 1998 when Viagra first approved. The data are from the Current Population Survey (CPS) of the Bureau of Census for the Bureau of Labor Statistics. 


\section{Appendix}

TABLE A.1: Impact of Viagra on Log Rate of Gonorrhea Cases 1990-2011: US Males

\begin{tabular}{|c|c|c|c|c|c|c|c|c|}
\hline & \multicolumn{2}{|c|}{--------------1996-2011-------------- } & \multicolumn{2}{|c|}{--------------1990-2007-------------- } & \multicolumn{2}{|c|}{--------------1995-2007-------------- } & \multicolumn{2}{|c|}{--------------1995-2011-------------- } \\
\hline & $\begin{array}{l}\text { Least } \\
\text { Squares }\end{array}$ & Poisson & Least Squares & Poisson & Least Squares & Poisson & Least Squares & Poisson \\
\hline & $(8)$ & (9) & $(10)$ & $(11)$ & $(12)$ & $(13)$ & $(14)$ & $(15)$ \\
\hline Viagra & $\begin{array}{c}0.110 \\
(0.054)^{*}\end{array}$ & $\begin{array}{c}0.132 \\
(0.062)^{* *}\end{array}$ & $\begin{array}{c}0.310 \\
(0.046)^{* * *}\end{array}$ & $\begin{array}{c}0.244 \\
(0.065)^{* * *}\end{array}$ & $\begin{array}{c}0.184 \\
(0.050)^{* * *}\end{array}$ & $\begin{array}{c}0.181 \\
(0.051)^{* * *}\end{array}$ & $\begin{array}{c}0.155 \\
(0.051)^{* * *}\end{array}$ & $\begin{array}{c}0.165 \\
(0.048)^{* * *}\end{array}$ \\
\hline $45+$ & $\begin{array}{c}-3.716 \\
(0.077)^{* * *}\end{array}$ & $\begin{array}{c}-3.627 \\
(0.077)^{* * *}\end{array}$ & $\begin{array}{l}-3.887 \\
(0.066)^{* * *}\end{array}$ & $\begin{array}{l}-3.723 \\
(0.076)^{* * *}\end{array}$ & $\begin{array}{l}-3.761 \\
(0.067)^{* * *}\end{array}$ & $\begin{array}{l}-3.660 \\
(0.078)^{* * *}\end{array}$ & $\begin{array}{l}-3.761 \\
(0.067)^{* * *}\end{array}$ & $\begin{array}{c}-3.660 \\
(0.078)^{* * *}\end{array}$ \\
\hline$t>1998$ & $\begin{array}{c}0.069 \\
(0.037)^{*}\end{array}$ & $\begin{array}{c}0.040 \\
(0.035)\end{array}$ & $\begin{array}{l}-0.017 \\
(0.067)\end{array}$ & $\begin{array}{c}0.166 \\
(0.037)^{* * *}\end{array}$ & $\begin{array}{l}-0.150 \\
(0.038)^{* * *}\end{array}$ & $\begin{array}{c}-0.093 \\
(0.035) * * *\end{array}$ & $\begin{array}{c}0.028 \\
(0.039)\end{array}$ & $\begin{array}{l}-0.008 \\
(0.036)\end{array}$ \\
\hline Linear trend & $\begin{array}{c}0.003 \\
(0.006)\end{array}$ & $\begin{array}{c}0.010 \\
(0.005)^{*}\end{array}$ & $\begin{array}{l}-0.017 \\
(0.007)^{* *}\end{array}$ & $\begin{array}{l}-0.042 \\
(0.009)^{* * *}\end{array}$ & $\begin{array}{c}0.032 \\
(0.007)^{* * *}\end{array}$ & $\begin{array}{c}0.023 \\
(0.007)^{* * *}\end{array}$ & $\begin{array}{c}0.002 \\
(0.005)\end{array}$ & $\begin{array}{c}0.008 \\
(0.006)\end{array}$ \\
\hline State FE & Yes & Yes & Yes & Yes & Yes & Yes & Yes & Yes \\
\hline Adjusted $R^{2}$ & 0.98 & $\cdot$ & 0.97 & $\cdot$ & 0.98 & $\cdot$ & 0.98 & $\cdot$ \\
\hline$R^{2}$ & 0.98 & 0.92 & 0.97 & 0.90 & 0.98 & 0.92 & 0.98 & 0.91 \\
\hline$N$ & 608 & 1632 & 864 & 1834 & 494 & 1326 & 646 & 1734 \\
\hline
\end{tabular}

$* p<0.1 ; * * p<0.05 ; * * * p<0.01$. All columns have standard errors clustered at the state level.

Least squares specifications drop 32 states that ever have less than 10 cases in a given age category in a given year.

Note that in 1999 there were 30,687 reported cases of gonorrhea in males 25-40 and 1,326 in males 45+. 
TABLE A.2: Impact of Viagra on Log Rate of Gonorrhea Cases 1990-2011: US Females

\begin{tabular}{|c|c|c|c|c|c|c|c|c|}
\hline & \multicolumn{2}{|c|}{$\begin{array}{c}\text {-------------1996-2011----------- } \\
--\end{array}$} & \multicolumn{2}{|c|}{--------------1990-2007-------------- } & \multicolumn{2}{|c|}{--------------1995-2007-------------- } & \multicolumn{2}{|c|}{--------------1995-2011-------------- } \\
\hline & $\begin{array}{l}\text { Least } \\
\text { Squares }\end{array}$ & Poisson & Least Squares & Poisson & Least Squares & Poisson & Least Squares & Poisson \\
\hline & (8) & (9) & $(10)$ & $(11)$ & $(12)$ & $(13)$ & (14) & $(15)$ \\
\hline Viagra & $\begin{array}{l}-0.046 \\
(0.036)\end{array}$ & $\begin{array}{l}-0.012 \\
(0.034)\end{array}$ & $\begin{array}{l}0.142 \\
(0.051)^{* *}\end{array}$ & $\begin{array}{l}0.121 \\
(0.050)^{* *}\end{array}$ & $\begin{array}{c}0.033 \\
(0.037)\end{array}$ & $\begin{array}{c}0.023 \\
(0.040)\end{array}$ & $\begin{array}{l}-0.033 \\
(0.037)\end{array}$ & $\begin{array}{l}-0.010 \\
(0.039)\end{array}$ \\
\hline $45+$ & $\begin{array}{c}-2.183 \\
(0.034)^{*} \\
* *\end{array}$ & $\begin{array}{l}-2.152 \\
(0.049)^{* * *}\end{array}$ & $\begin{array}{l}-2.306 \\
(0.043)^{* * *}\end{array}$ & $\begin{array}{l}-2.253 \\
(0.070)^{* * *}\end{array}$ & $\begin{array}{l}-2.197 \\
(0.031)^{* * *}\end{array}$ & $\begin{array}{l}-2.155 \\
(0.059)^{* * *}\end{array}$ & $\begin{array}{l}-2.197 \\
(0.031)^{* * *}\end{array}$ & $\begin{array}{l}-2.155 \\
(0.059)^{* * *}\end{array}$ \\
\hline$t>1998$ & $\begin{array}{c}0.264 \\
(0.037)^{*} \\
* *\end{array}$ & $\begin{array}{c}0.104 \\
(0.050)^{* *}\end{array}$ & $\begin{array}{c}0.130 \\
(0.069)^{*}\end{array}$ & $\begin{array}{l}0.247 \\
(0.037)^{* * *}\end{array}$ & $\begin{array}{c}0.042 \\
(0.045)\end{array}$ & $\begin{array}{c}0.001 \\
(0.045)\end{array}$ & $\begin{array}{l}0.237 \\
(0.041)^{* * *}\end{array}$ & $\begin{array}{c}0.070 \\
(0.056)\end{array}$ \\
\hline Linear trend & $\begin{array}{c}-0.041 \\
(0.008)^{*} \\
* *\end{array}$ & $\begin{array}{l}-0.028 \\
(0.006)^{* * *}\end{array}$ & $\begin{array}{l}-0.048 \\
(0.006)^{* * *}\end{array}$ & $\begin{array}{l}-0.076 \\
(0.011)^{* * *}\end{array}$ & $\begin{array}{l}-0.012 \\
(0.009)\end{array}$ & $\begin{array}{l}-0.017 \\
(0.008)^{* *}\end{array}$ & $\begin{array}{l}-0.042 \\
(0.008)^{* * *}\end{array}$ & $\begin{array}{l}-0.029 \\
(0.006)^{* * *}\end{array}$ \\
\hline State FE & Yes & Yew & Yes & Yes & Yes & Yes & Yes & Yes \\
\hline Adjusted $R^{2}$ & 0.96 & • & 0.96 & $\cdot$ & 0.97 & $\cdot$ & 0.96 & $\cdot$ \\
\hline$R^{2}$ & 0.96 & 0.91 & 0.96 & 0.91 & 0.97 & 0.92 & 0.960 & 0.91 \\
\hline$N$ & 608 & 1,632 & 684 & 1,834 & 494 & 1,326 & 646 & 1,734 \\
\hline
\end{tabular}

$* p<0.1 ; * * p<0.05 ; * * * p<0.01$, all columns have standard errors clustered at the state level.

Least Squares specifications drop 32 states that ever have less than 10 cases in a given age category in a given year

Note that in 1999 there were 55,071 reported cases of gonorrhea in females 25-40 and 8,169 in females 45+ 
TABLE A.4: Impact of Viagra on log rate of rape arrests of US males: 1994-2010

\begin{tabular}{|c|c|c|c|c|c|c|c|c|}
\hline & \multicolumn{2}{|c|}{-------------1996-2011-------------- } & \multicolumn{2}{|c|}{--------------1994-2007-------------- } & \multicolumn{2}{|c|}{--------------1995-2007-------------- } & \multicolumn{2}{|c|}{--------------1995-2011-------------- } \\
\hline & Least Squares & Poisson & Least Squares & Poisson & Least Squares & Poisson & $\begin{array}{c}\text { Least } \\
\text { Squares }\end{array}$ & Poisson \\
\hline & (8) & (9) & $(10)$ & $(11)$ & $(12)$ & (13) & (14) & (15) \\
\hline Viagra & $\begin{array}{l}-0.030 \\
(0.045)\end{array}$ & $\begin{array}{l}-0.010 \\
(0.039)\end{array}$ & $\begin{array}{l}-0.014 \\
(0.051)\end{array}$ & $\begin{array}{l}-0.008 \\
(0.040)\end{array}$ & $\begin{array}{l}-0.014 \\
(0.051)\end{array}$ & $\begin{array}{l}-0.007 \\
(0.040)\end{array}$ & $\begin{array}{l}-0.022 \\
(0.042)\end{array}$ & $\begin{array}{l}-0.012 \\
(0.047)\end{array}$ \\
\hline $45+$ & $\begin{array}{l}-1.805 \\
(0.060)^{* * *}\end{array}$ & $\begin{array}{l}-1.879 \\
(0.049)^{* * *}\end{array}$ & $\begin{array}{l}-1.803 \\
(0.064) * * *\end{array}$ & $\begin{array}{l}-1.874 \\
(0.063)^{* * *}\end{array}$ & $\begin{array}{l}-1.814 \\
(0.069) * * *\end{array}$ & $\begin{array}{l}-1.871 \\
(0.060)^{* * *}\end{array}$ & $\begin{array}{l}-1.819 \\
(0.061)^{* * *}\end{array}$ & $\begin{array}{l}-1.875 \\
(0.059)^{* * *}\end{array}$ \\
\hline t>1998 & $\begin{array}{l}-0.020 \\
(0.028)\end{array}$ & $\begin{array}{c}0.028 \\
(0.040)\end{array}$ & $\begin{array}{l}-0.059 \\
(0.038)\end{array}$ & $\begin{array}{l}-0.027 \\
(0.049)\end{array}$ & $\begin{array}{l}-0.059 \\
(0.038)\end{array}$ & $\begin{array}{l}-0.029 \\
(0.050)\end{array}$ & $\begin{array}{l}-0.025 \\
(0.029)\end{array}$ & $\begin{array}{c}0.029 \\
(0.041)\end{array}$ \\
\hline $\begin{array}{l}\text { Linear } \\
\text { trend }\end{array}$ & $\begin{array}{l}-0.043 \\
(0.004)^{* * *}\end{array}$ & $\begin{array}{l}-0.027 \\
(0.004)^{* * *}\end{array}$ & $\begin{array}{c}-0.036 \\
(0.005) * * *\end{array}$ & $\begin{array}{l}-0.019 \\
(0.005)^{* * *}\end{array}$ & $\begin{array}{l}-0.037 \\
(0.006)^{* * *}\end{array}$ & $\begin{array}{l}-0.016 \\
(0.006)^{* *}\end{array}$ & $\begin{array}{l}-0.043 \\
(0.004)^{* * *}\end{array}$ & $\begin{array}{c}-0.027 \\
(0.004)^{* * *}\end{array}$ \\
\hline $\begin{array}{l}\text { State } \\
\text { FE }\end{array}$ & & & & & & & & \\
\hline $\begin{array}{l}\text { Adjuste } \\
d R^{2}\end{array}$ & 0.84 & . & 0.84 & . & 0.85 & . & 0.84 & . \\
\hline$R^{2}$ & 0.84 & 0.52 & 0.85 & 0.54 & 0.85 & 0.54 & 0.84 & 0.52 \\
\hline$N$ & 2,250 & 16,110 & 2,100 & 15,036 & 1,950 & 13,962 & 2,400 & 17,184 \\
\hline
\end{tabular}

$* p<0.1 ; * * p<0.05 ; * * * p<0.01$, all columns have standard errors clustered at the state level.

Least Squares specifications drop 32 states that ever have less than 10 cases in a given age category in a given year 
TABLE A.5: Impact of Viagra on log rate of sexual offense arrests of US males: 1994-2010

\begin{tabular}{|c|c|c|c|c|c|c|c|c|}
\hline & \multicolumn{2}{|c|}{-------------1996-2011------------- } & \multicolumn{2}{|c|}{-------------1994-2007------------- } & \multicolumn{2}{|c|}{-------------1995-2007------------- } & \multicolumn{2}{|c|}{-------------1995-2011------------- } \\
\hline & Least Squares & Poisson & Least Squares & Poisson & Least Squares & Poisson & Least Squares & Poisson \\
\hline & (8) & (9) & (10) & (11) & (12) & (13) & (14) & (15) \\
\hline Viagra & $\begin{array}{l}-0.049 \\
(0.029) *\end{array}$ & $\begin{array}{l}-0.026 \\
(0.034)\end{array}$ & $\begin{array}{l}-0.042 \\
(0.032)\end{array}$ & $\begin{array}{l}-0.004 \\
(0.035)\end{array}$ & $\begin{array}{l}-0.042 \\
(0.032)\end{array}$ & $\begin{array}{l}-0.004 \\
(0.035)\end{array}$ & $\begin{array}{l}-0.048 \\
(0.025) *\end{array}$ & $\begin{array}{l}-0.036 \\
(0.033)\end{array}$ \\
\hline $45+$ & $\begin{array}{l}-1.139 \\
(0.041)^{* * *}\end{array}$ & $\begin{array}{l}-1.219 \\
(0.035)^{* * *}\end{array}$ & $\begin{array}{l}-1.140 \\
(0.028)^{* * *}\end{array}$ & $\begin{array}{l}-1.160 \\
(0.027)^{* * *}\end{array}$ & $\begin{array}{l}-1.136 \\
(0.033)^{* * *}\end{array}$ & $\begin{array}{l}-1.179 \\
(0.030)^{* * *}\end{array}$ & $\begin{array}{l}-1.141 \\
(0.034)^{* * *}\end{array}$ & $\begin{array}{l}-1.200 \\
(0.031)^{* * *}\end{array}$ \\
\hline$t>1998$ & $\begin{array}{c}0.025 \\
(0.039)\end{array}$ & $\begin{array}{c}0.038 \\
(0.031)\end{array}$ & $\begin{array}{l}-0.031 \\
(0.038)\end{array}$ & $\begin{array}{l}-0.017 \\
(0.033)\end{array}$ & $\begin{array}{l}-0.031 \\
(0.038)\end{array}$ & $\begin{array}{l}-0.018 \\
(0.033)\end{array}$ & $\begin{array}{c}0.031 \\
(0.039)\end{array}$ & $\begin{array}{c}0.048 \\
(0.031)\end{array}$ \\
\hline $\begin{array}{l}\text { Linear } \\
\text { trend }\end{array}$ & -0.031 & -0.020 & -0.020 & -0.009 & -0.019 & -0.007 & -0.030 & -0.020 \\
\hline State FE & $(0.004)^{* * *}$ & $(0.004)^{* * *}$ & $(0.005)^{* * *}$ & $(0.005)^{*}$ & $(0.005)^{* * *}$ & $(0.005)$ & $(0.004)^{* * *}$ & $(0.004)^{* * *}$ \\
\hline $\begin{array}{l}\text { Adjuste } \\
d R^{2}\end{array}$ & 0.76 & . & 0.76 & . & 0.76 & . & 0.75 & . \\
\hline$R^{2}$ & 0.77 & 0.55 & 0.77 & 0.56 & 0.77 & 0.56 & 0.76 & 0.54 \\
\hline$N$ & 8,550 & 26,130 & 7,980 & 24,388 & 7,410 & 22,646 & 9,120 & 27,872 \\
\hline
\end{tabular}

$* p<0.1 ; * * p<0.05 ; * * * p<0.01$, all columns have standard errors clustered at the state level.

Least Squares specifications drop 32 states that ever have less than 10 cases in a given age category in a given year 